\title{
Research Paper \\ The Relationship between Parental Conflict Resolution Strategies and Attachment Styles with Quality of Life in Adolescent Girls with Loneliness Feeling
}

\author{
Maryam Khorami Ghaziyani ${ }^{1}$, Abbas Abolghasemi ${ }^{* 2}$ \\ 1. M.A. in Clinical Psychology, Ardabil Branch, Islamic Azad University, Ardabil, Iran \\ 2. Professor, Department of Psychology, Faculty of Literature and Humanities, University of Guilan, Rasht, Iran
}

Citation: Khorami Ghaziyani M, Abolghasemi A. The relationship between parental conflict resolution strategies and attachment styles with quality of life in adolescent girls with loneliness feeling. Quarterly Journal of Child Mental Health. 2020; 7(1): 1-14.

$\underline{\text { http://dx.doi.org/10.29252/jcmh.7.1.2 }}$

\section{A R T I C L E I N F O}

\begin{tabular}{l}
\hline Keywords: \\
Conflict resolution, \\
attachment styles, \\
quality of life, \\
loneliness
\end{tabular}

Received: 25 Apr 2018

Accepted: 6 Jun 2019

Available: 5 may 2020

\begin{abstract}
A B S T R A C T
Background and Purpose: Loneliness is an unpleasant state that results from differences in the interpersonal relationships desired by individuals and affects the quality of their life. This study aimed to investigate the relationship between parental conflict resolution strategies and attachment styles and quality of life among adolescent girls with loneliness feeling.

Method: It is a descriptive correlational research. The population consisted of all female 13 to 15 year old students in Rasht in the academic year of 2015-2016. A sample of 120 female students with loneliness was selected through cluster sampling method. World Health Organization Quality of Life Questionnaire (1989), Loneliness Questionnaire (Asher et al., 1984), Parent-Child Conflict Tactics Scale (Straus, 1990), and Adult Attachment Scale (Hazen \& Shaver, 1987) were used to collect data. Data were analyzed by Pearson correlation coefficient and Multiple Regression Analysis.

Results: There was a significant positive relationship between parent's reasoning and quality of life $(\mathrm{p}<0.01)$, a significant negative relationship between mother's physical aggression and the quality of life of the girls $(\mathrm{p}<0.01)$, and a significant negative relationship between insecure attachment style and quality of life of girls with loneliness feelings $(\mathrm{p}<0.05)$. Multiple regression results showed that parental conflict resolution strategies and attachment styles can predict the quality of life and loneliness feeling of girls $31 \%(\mathrm{p}<0.01)$ and $19 \%$, respectively.

Conclusion: Based on the finding of the present research, it can be concluded parental conflict resolution strategies and children attachment styles play role in the quality of life of girls with loneliness. Therefore, to enhance the students' quality of life and to improve parent-child relationships, it is necessary to teach them the correct conversation practices, conflict resolution strategies, and identify appropriate attachment styles.
\end{abstract}

\footnotetext{
* Corresponding author: Abbas Abolghasemi, Professor, Department of Psychology, Faculty of Literature and Humanities, University of Guilan, Rasht, Iran.

E-mail addresses: Abolghasemi1344@guilan.ac.ir
} 


\title{
رابطه شيوههاى حل تعارض والدين و سبكتهاى دلبستكى با كيفيت زندكى دختران داراى احساس تنهايى
}

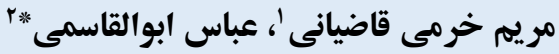

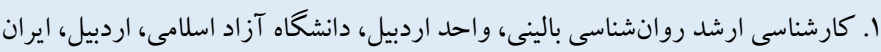

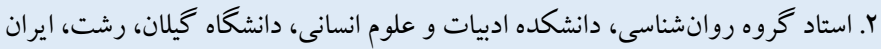

زمينه و هدف: احساس تنهايى حالتى ناخوشايند است كه از تفاوت در روابط بين فردى كه افراد خواهان آن هستند، نشات كرفته و كيفيت

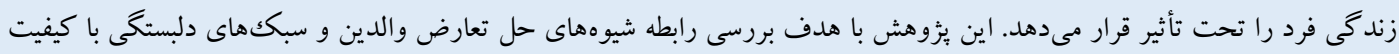
زندگى دختران نوجوان داراى احساس تنهايى انجام شد.

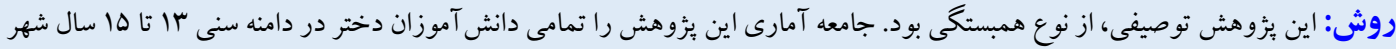

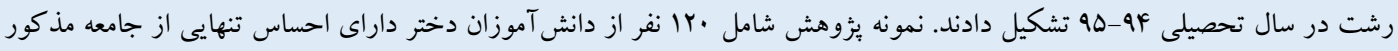

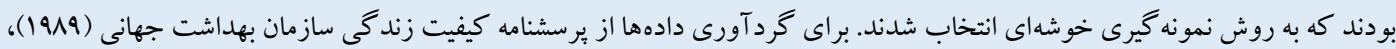

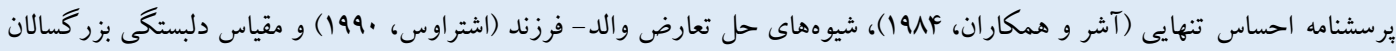

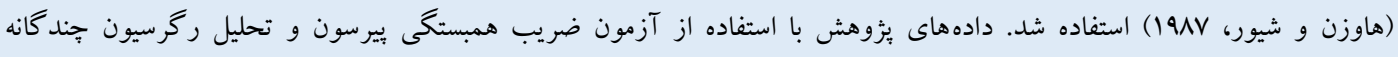
تجزيهوتحليل شدند.

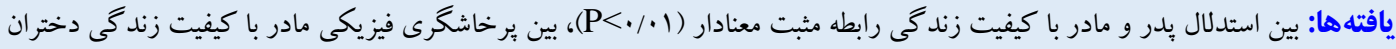

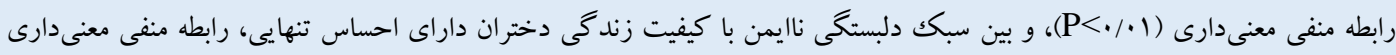

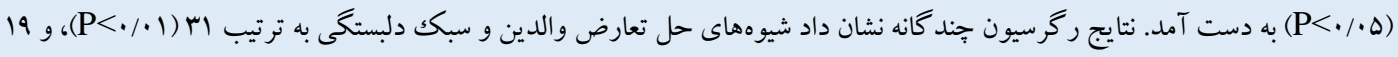

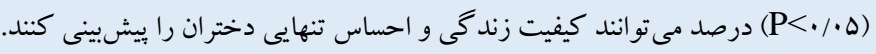

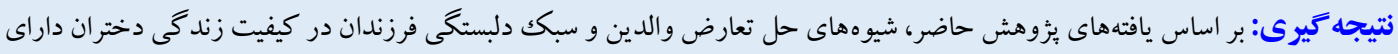

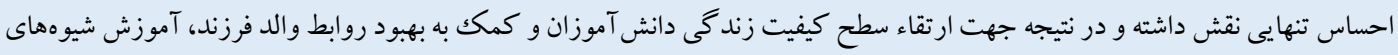

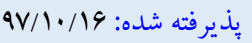

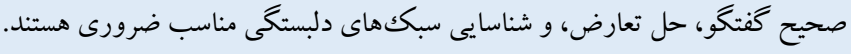


آنها فراهم كرد (V). احسـاس تنهايى ييامدهايى مانند افسردگىى، كاهش

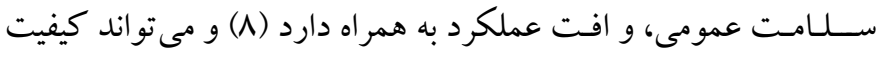

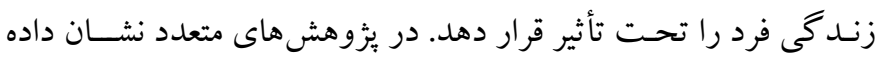

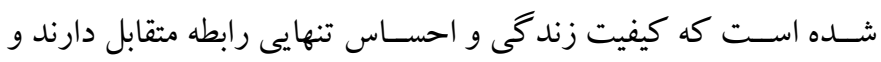

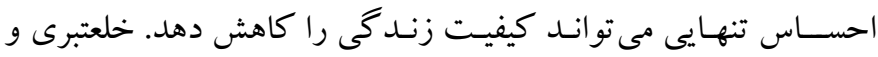
همكاران نيز در يزٔوهشى نشان دادند كه احساس تنهايى، تبيين كننده قوى تورى

$$
\text { براى كيفيت زندگى دانشجويان است (9). }
$$

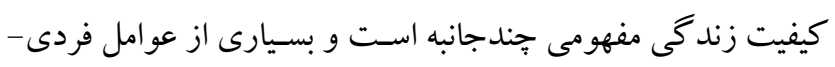

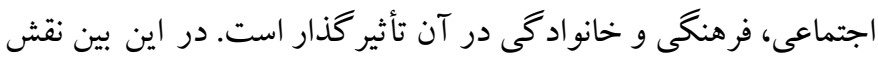

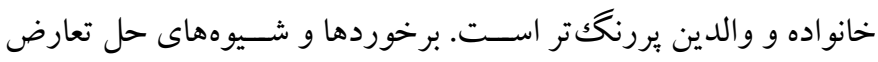

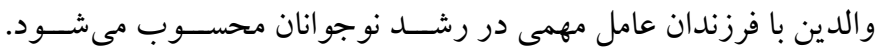

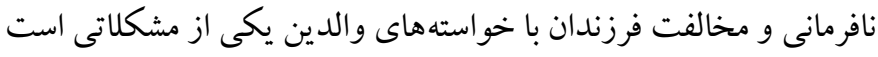

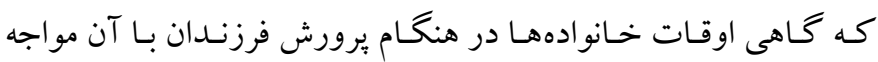

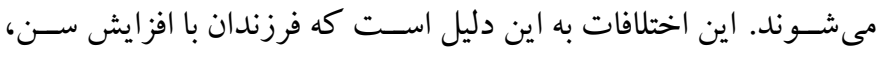

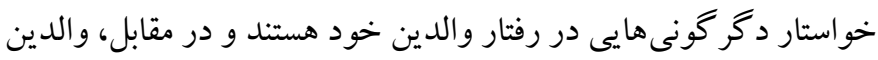

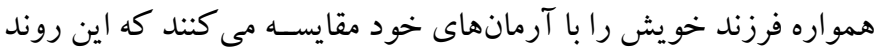
موجب تشـديد تعارضها و سازشنايافتخىهاى بين والد- فرزند مى شود

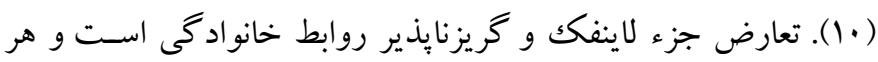
جه روابط صـميمانهتر باشـد، احتمال تعارض بينفردى بيشـتر مىشـود.

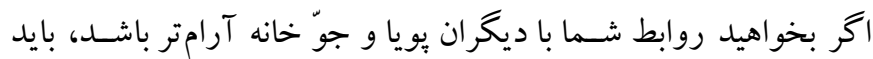

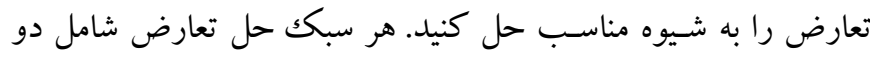

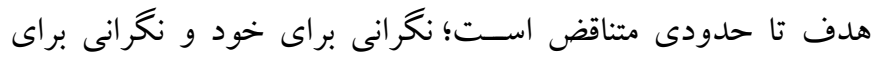

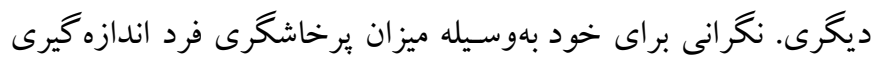

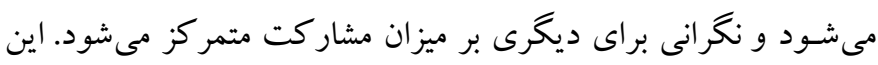

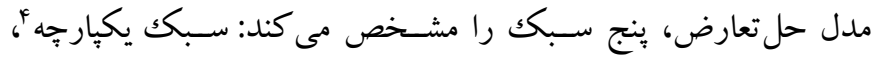

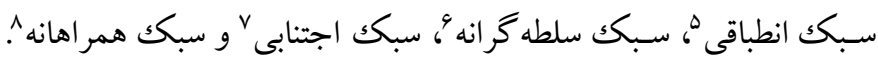

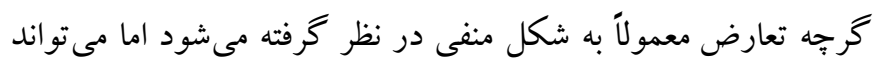

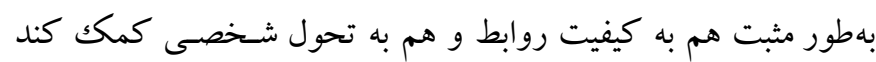

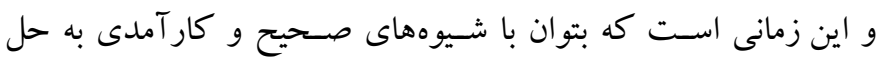

5. Accommodating

6. Dominating

7. Avoiding

8. Obliging
مقدمه

نوجوانى دورهاى از زندگى اسـت كه در آن تغييرات بسـيارى در

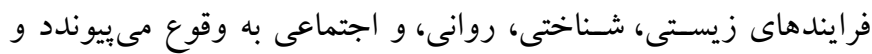

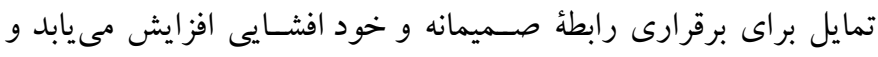

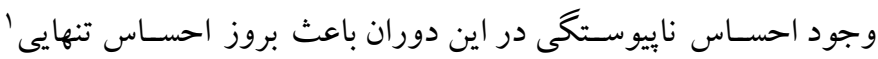

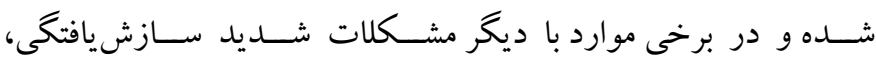
افسرد گى، و خود كشى مرتبط اسـت (1). مشـكلات احسـاس تنهايى و

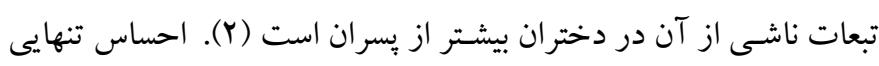
حالتى ناخوشايند است كه از تفاوت در روابط بين فردى كه افر اد خواهان آن هسـتنــد و روابطى كـه با ديخران در شــــايط واقعى دارند، نشــأت

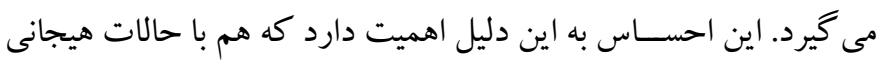

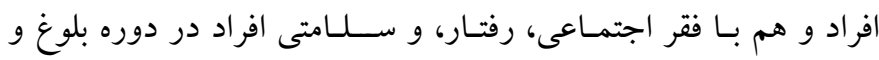

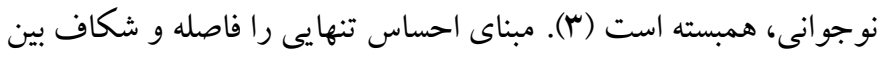
آرمآنهاى فرد (آنجه مى خو اهد) و دستاوردهاى او (آنجه به دست آورده اسـت) در روابط و صـميميتهاى بينفردى تعريف مى كند؛ هر جه اين فاصله بيشتر باشد، احساس تنهايى بيشتر است (F). احساس تنهايى، زمانى صنى

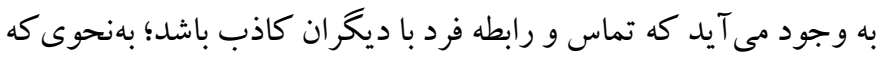

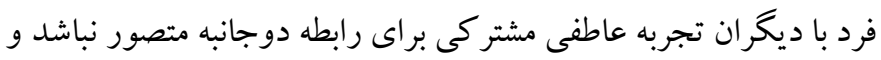

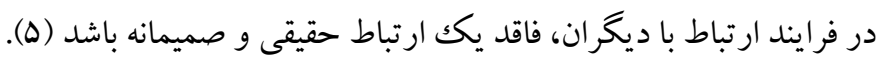

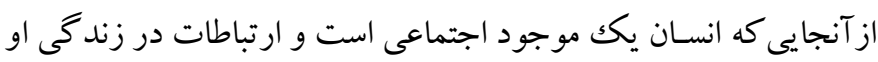

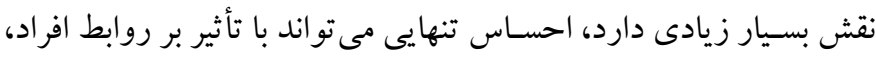

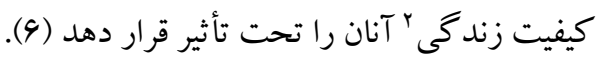

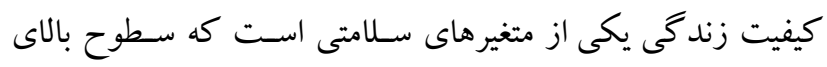

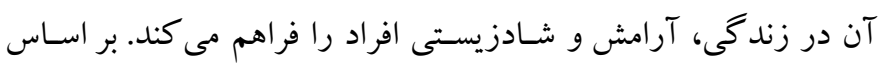

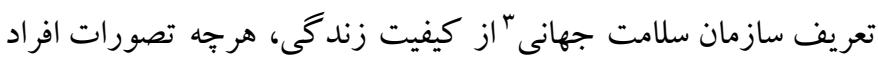

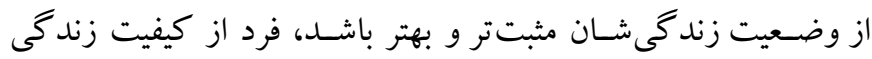

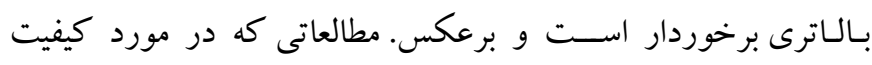

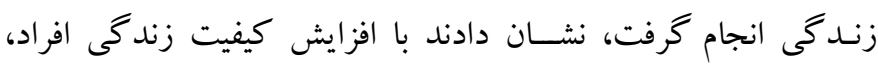

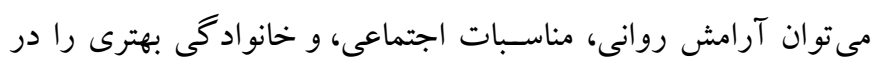

1. Loneliness feeling

2. Quality of Life

3. World Health Organization

4 . Integrating 
مراقبت از آنها را به عهده دارند، تأكيد كرده و اين كنشهاى متقابل را اسـاس عمده تحول ابعاد مختلف عاطفى، شـناختى و اجتماعى مى دانند

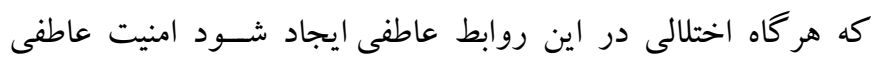

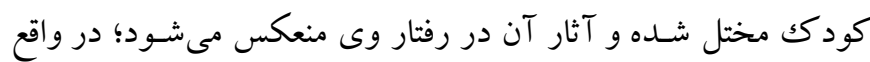

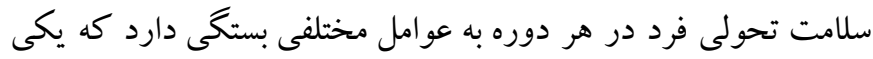

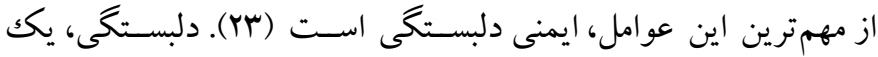

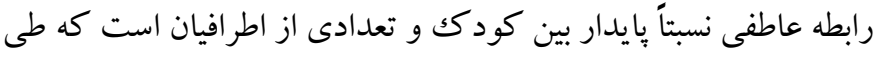

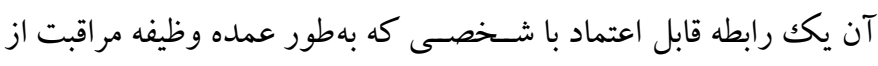

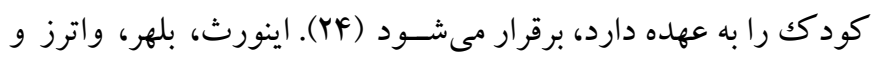

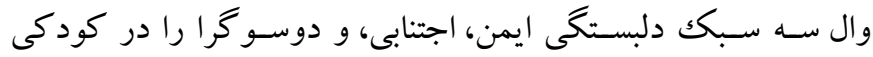
توصسيف كردند كه در بزرگسالى نيز مورد تأييد قرار گرفته است. اين

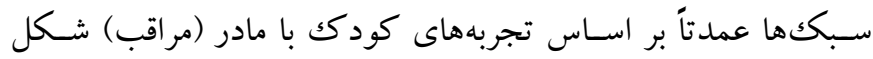

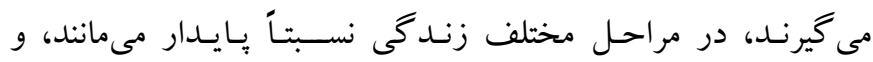

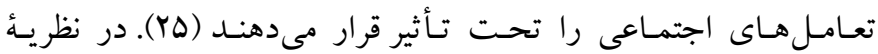

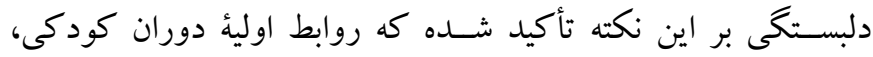

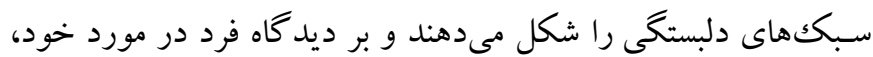
ديخران و روش سـازماندهى روابط بينفردى، تأثير مى گذارند (Y)).

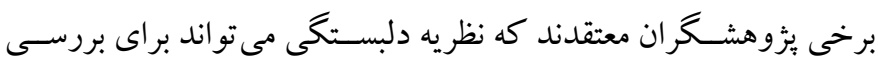

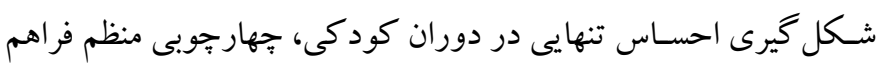

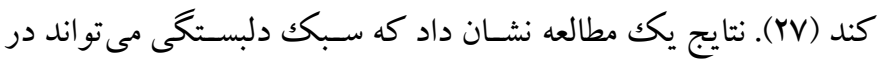

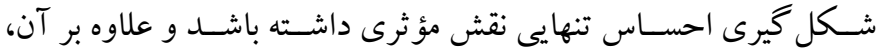
ارتباطات و شيوههاى حل تعارض خانو ادگى نيز در بروز احساس تنهايى

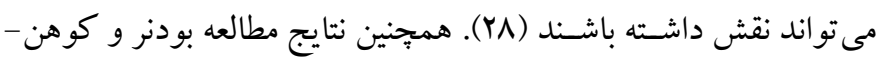

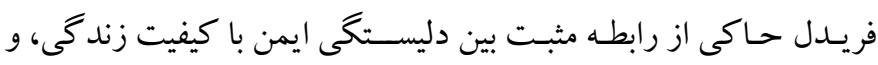

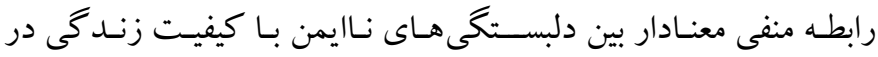

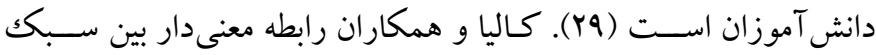
دلبستيخى نايمن اجتنابى با كيفيت زندگى (·r) و موريرا و همكاران نيز

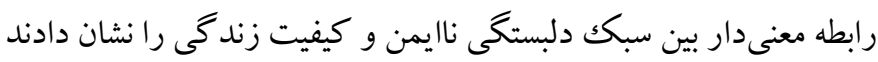

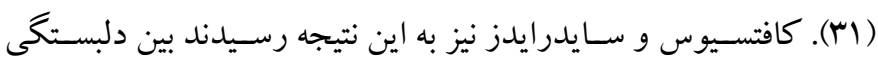
اضـطر ابى و رفـاه، رابطه معكوس وجود دارد كه اين رابطه معكوس در جوانان، قوى تر اسـت (rr). بالاخره نتايج بثوهش احدى حاكى از رابطه

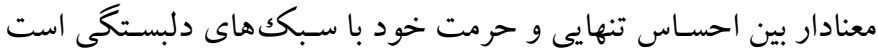

تعارض برداخت (11). از ســوى ديخر اداره تنيدگى و حل تعارض موجب ارتقاء سـلامتى، بيشـيرى از بروز بيمارىها، و بهبود كيفيت

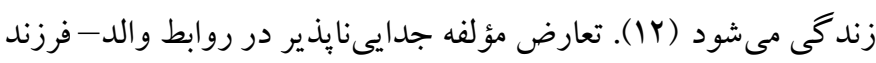

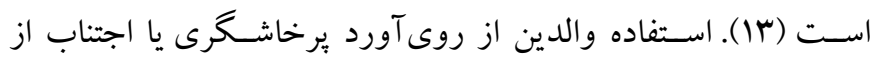
تعارض در حل تعارضـات با بسيارى از ييامدهاى منفى در كودكان

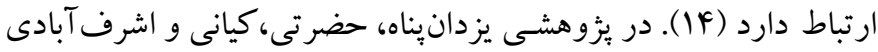

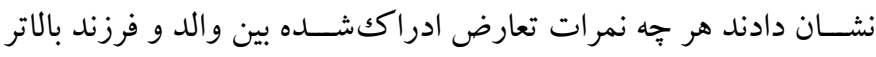
باشد، نمرات مربوط به افسردگى، اضطر اب، علائم جسمانى، و اختلال در

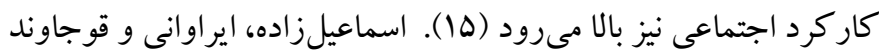

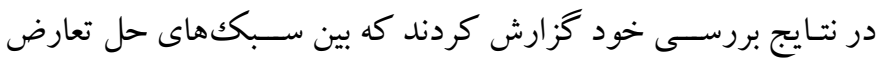

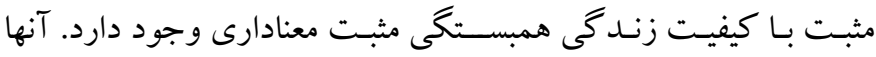

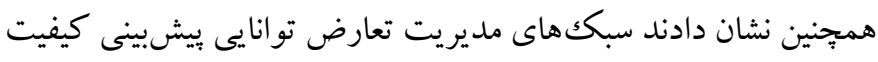

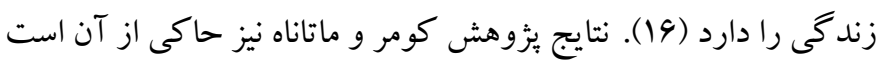
كه شيوههاى حل تعارض والدين مى تواند در فرزندان احساسات منفى از

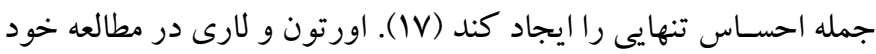
نشان دادند كه بين مؤلفه استدلال با سلامت روانى و كيفيت زندگ ركى رابطه مثبت معنادار، و بين برخاشـخرى كلامى و يرخاشخرى فيزيكى با سلامت

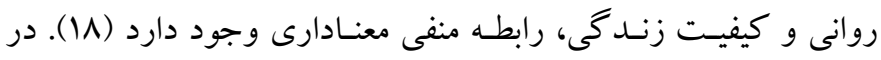

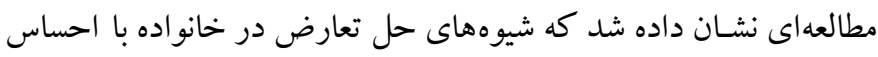

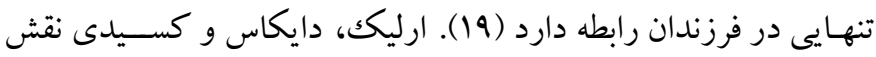
اسـتدلال والدين در حل تعارض رادر بهبود شـرايط و عملكرد اجتماعى

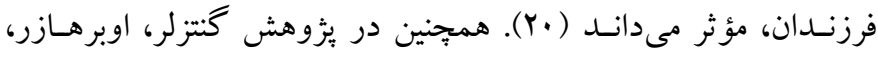

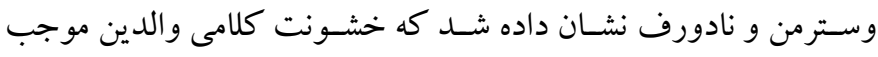

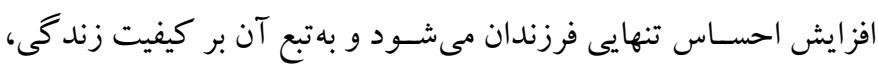
تأثير منفى دارد (Y) كيفيت زندگى هر فرد و جامعه با عوامل گوناگونى مرتبط اسـت.

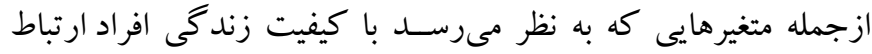

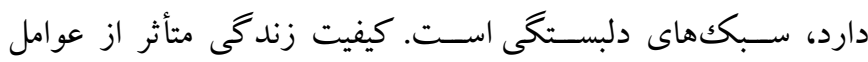
روانشـناختى و اجتماعى اسـت كه در اين بين سبككهاى دلبستخى به دانه دليل نقش بنيادى آنها در نحوه هدايت كشاكشها هـا و موضوعات متعدد درونفردى و بينفردى و تأثير آن در شـكل هدهى ادراكك فرد، حائز

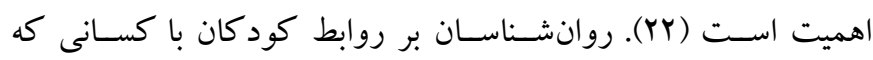


دانش آموزانى كـه داراى نمرات بـالـا در مقيـاس احســاس تنهايى بودند

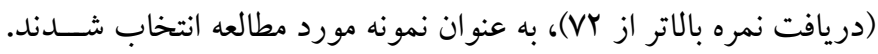
ملاكك تعيين حجم نمونه در اين مطالعه، فرمول ارائه شـده توسط فيدل و

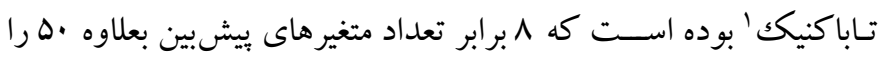

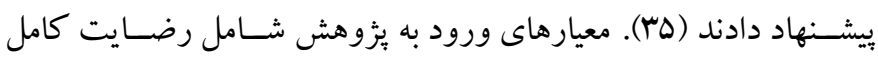

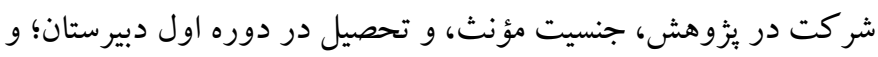

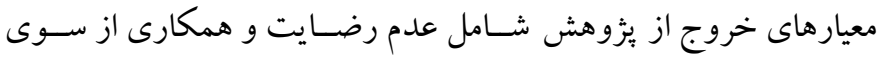
دانش آموز، و داشـتن سابقه بيمارى جسمانى صعب العلاج يا روانشناختى

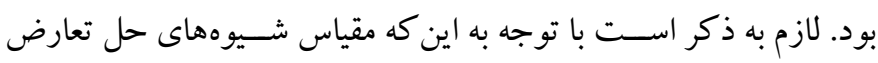

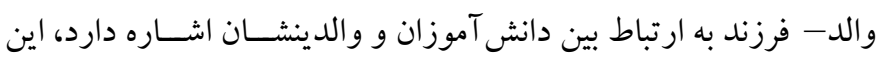
يرسشنامه توسط دانش آموزان تكميل شد.

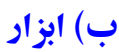

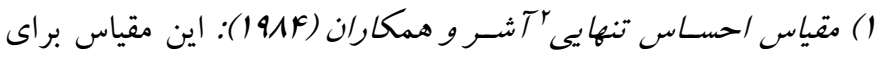
سنجش احساس تنهايى در دوره اواخر كودكى و بس از نوجوانى توسط

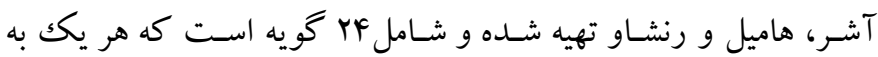
صـورت جملهاى خبرى با ضـمير فاعلى(من) بيان شـده اسـت. به منظور

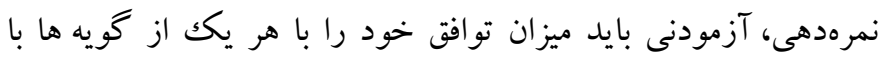

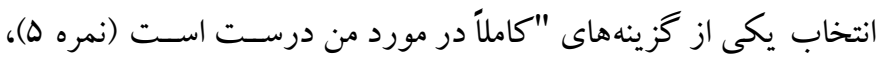

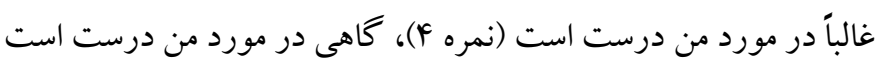

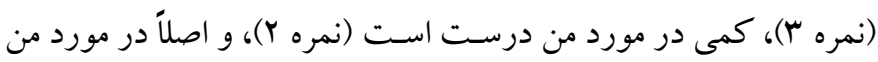

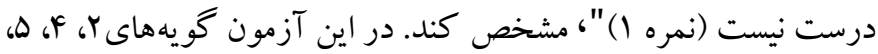

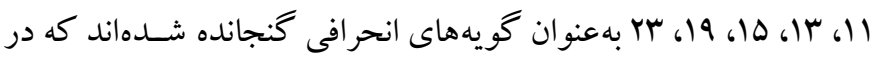

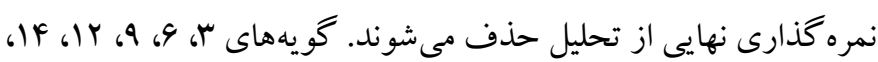

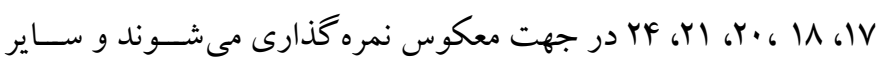

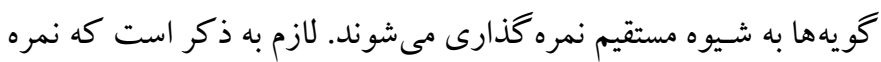

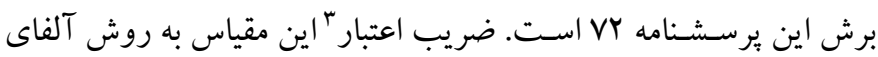

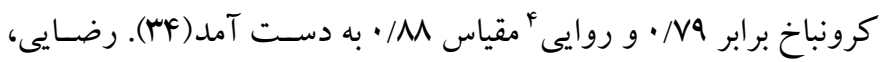
صفايى و هاشمى روايى صورى اين برسشنامه را مطلوب گز زارش كردند

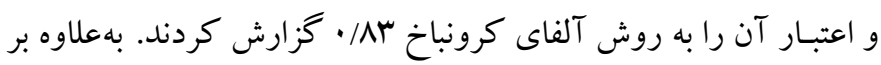

3. Reliability

4. Validity
(Tسا). با توجه به اينكه احسـاس تنهايى ييامدهايى دارد كه زندگى فرد را

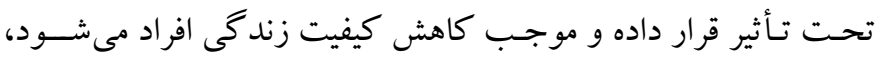

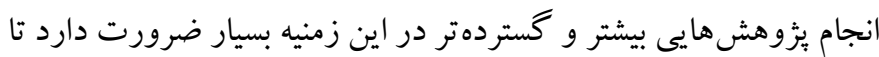

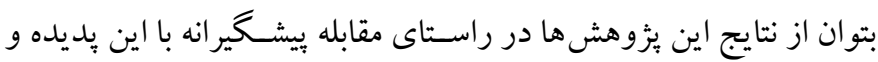

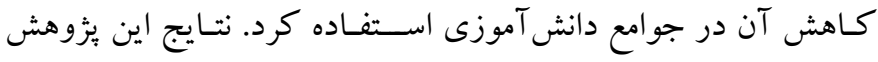

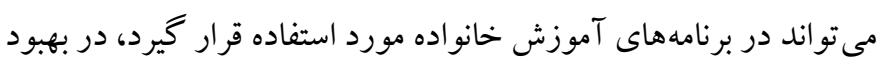

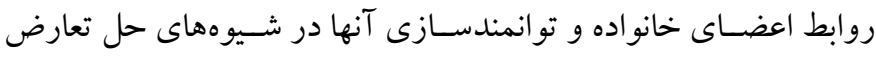

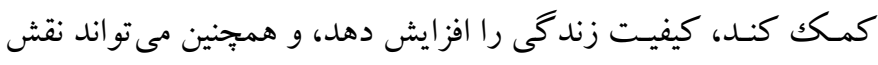
مؤثرى در كاهش احساس تنهايى داشته باشد.

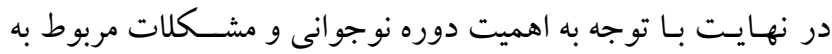

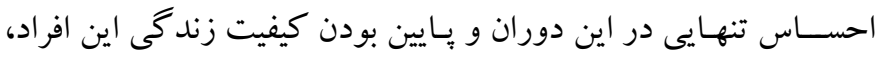

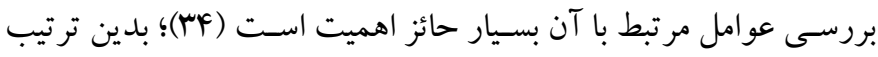

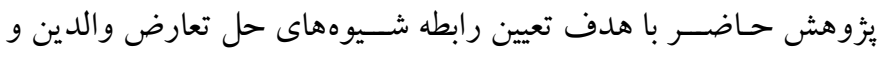

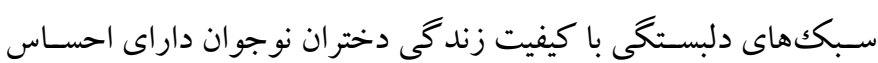
تنهايى، انجام شد.

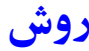
الف) طرح يزوهش و شـر كت كنند كان: روش اين يُوهش توصيفى،

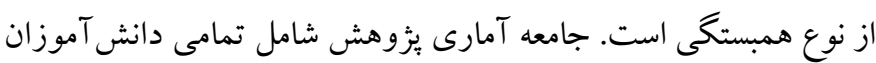
دختر دبيرستانى دوره اول در دامنه سنى بين با تا ها سال داراى احساس تنهايى شـهر رشــت در ســال تحصــلى

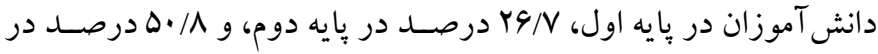
يايه سـوم مشـغول به تحصسيل بودند. در بين تحصسيلات والدين، كمترين

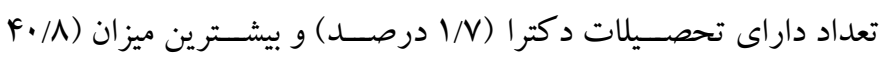
درصـد) داراى تحصـيلات زير دييلم بودند. ميانخين سـنى دانش آموزان

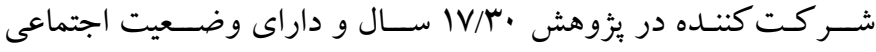
اقتصادى متوسط بودند. دانش آموزان به روش نمونه گيرى خوشهاى در

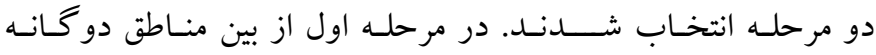

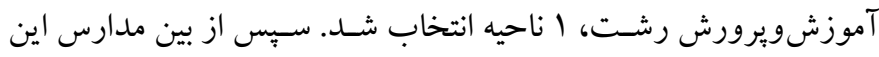

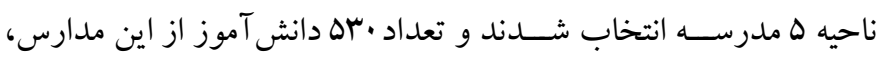

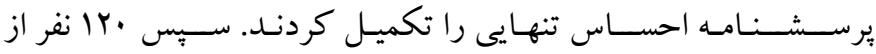

1. Tabachnick \& Fidell

2. Loneliness scale 
فيزيكى، 190/، •1M/•؛ راهبردهاى حل تعارض خود در بخش استـدلال

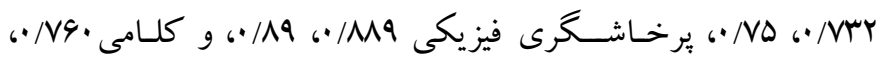
/VV

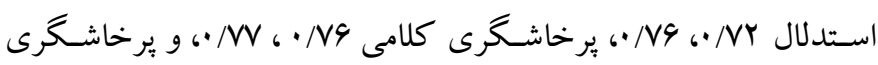

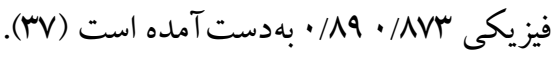

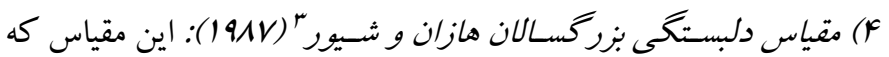

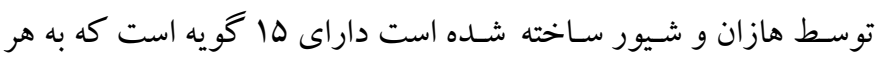

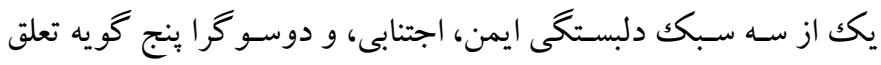
مى گيرد و نمره گذارى در مقياس ليكرت از هر گز (نمره صـفر ) تا تقريباً

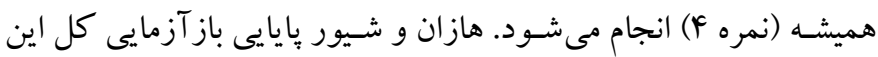

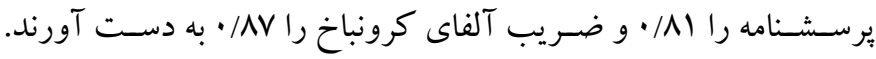

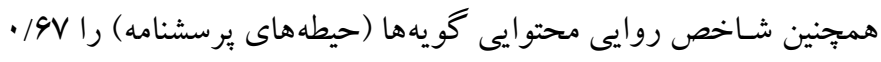

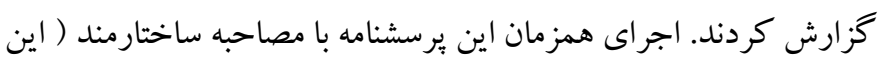

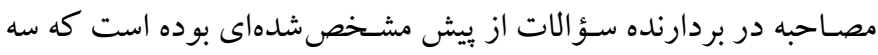

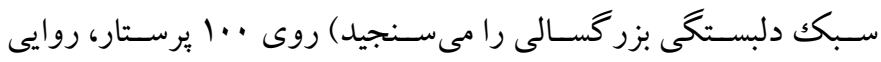

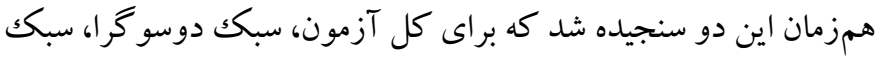

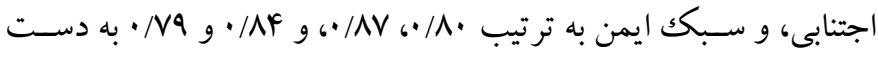

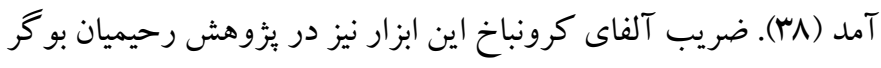

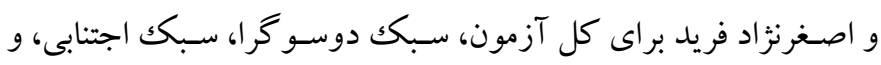

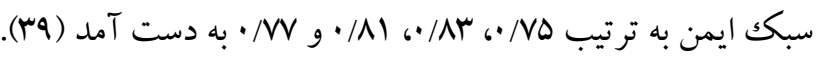

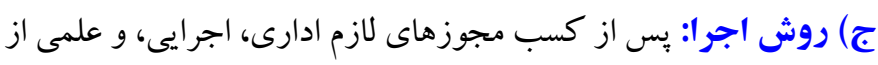

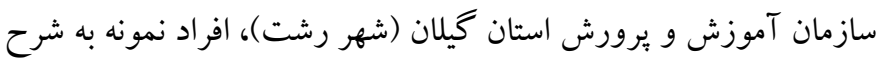
ارائه شده در بخش روش، انتخاب شدند و يرسشنامههاى اين مطالعه ضمن توضيح هدف هاى يثوهش و اطمينان از كسب رضايت آنها، اجرا شد.

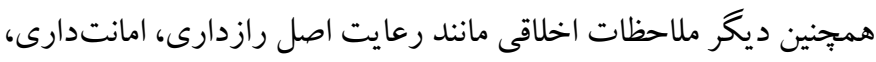
آزاد بودن براى انصراف از شركت در مطالعه در هر مرحله از انجام يُزوهش و نظاير آن به طور كامل در اين مطالعه رعايت شد. در نهايت

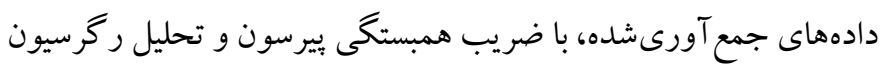
جند گانه به وسيله نرمافزار آمارى
آن اعتبار خردهمقياس احساس تنهايى عاطفى، شY/•و اعتبار خردهمقياس احساس تنهايى اجتماعى، ال//· به دست آمد (ه广).

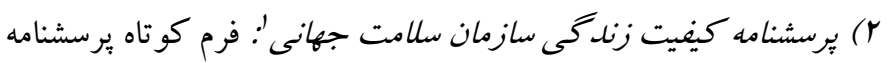

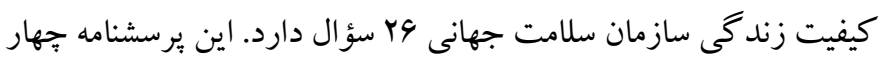
حيطه سـلامتى جسمانى، سلامتى روانى، روابط اجتماعى، و سلامتى محيط را با YF كويه مورد ســنش قرار مىدهد (هر يكك از حيطه ها به ترتيب

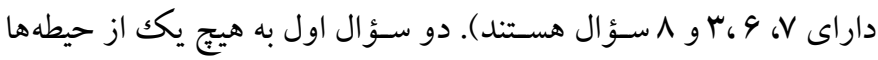

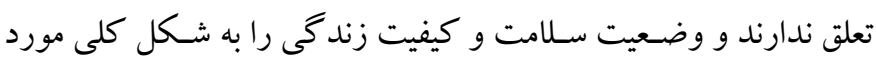

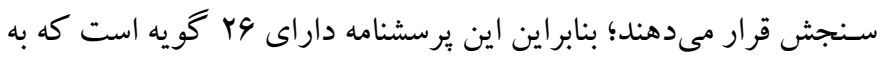
هر سـؤال از ا تا ها نمره داده مىشـود. اين برســـــامه بر اسـاس مقياس

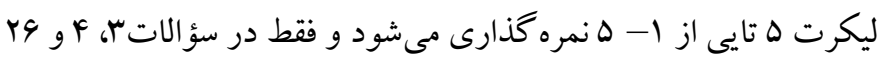

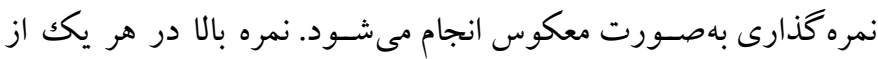

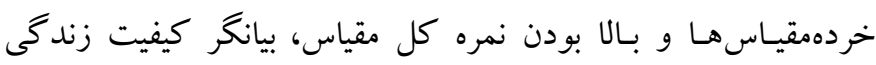

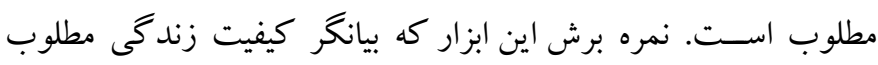
اسـت، نمره ·F اسـت. اين برســــامه در ايران توسط نجات و همكاران

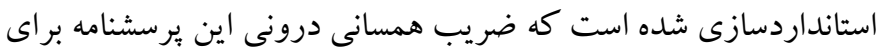

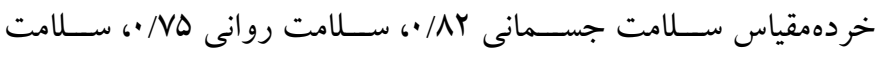

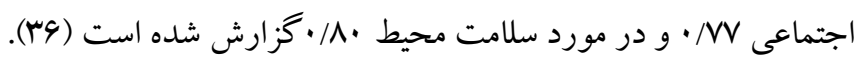

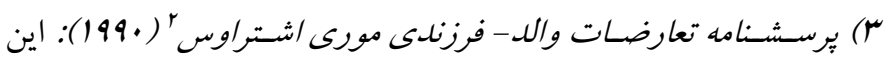

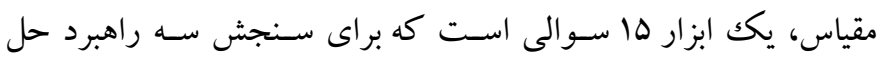

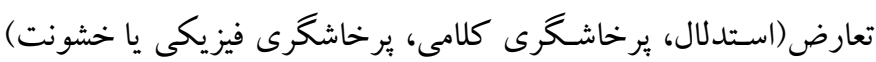

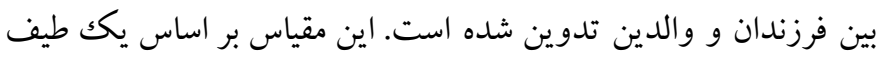

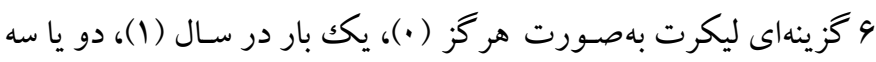

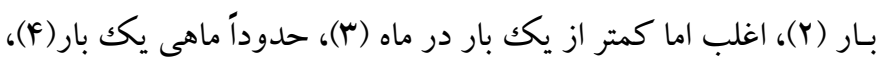

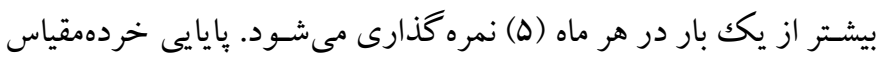

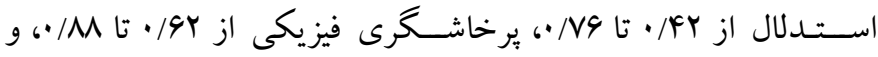

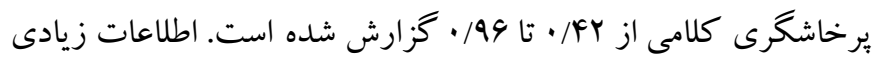

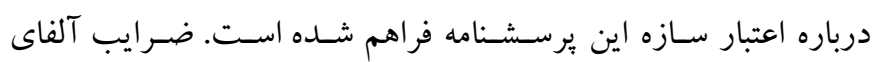

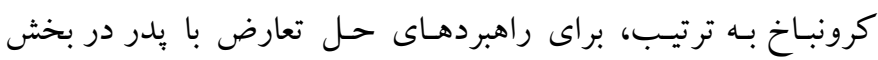

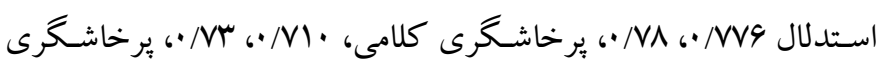

1. World Health Organization Quality of Life

2. Questionnaire of parent-child conflicts of Murray Straus

3. Adult Attachment Scale of Hazan \& Shaver 
يافتهها

بر اساس تحليل دادههاى به دست آمده از اجراى يرسشنامهها روس افراد

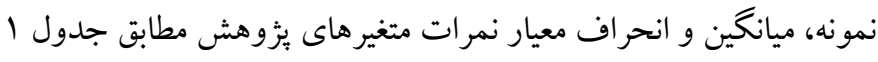
كزارش شده است.

جدول 1: ميانغين و انحر اف معيار متغيرهاى ثزوهش أن

\begin{tabular}{|c|c|c|c|c|}
\hline كشيدكى & جولكى & انحر اف استاندارد & ميانكين & متغير \\
\hline$-\cdot / 194$ &.$- \cdot 1 \cdot 9$ & $11 / 09$ & VG/rr & كيفيت زندگى \\
\hline$\cdot 11 \cdot 9$ & $-\cdot / 41$. & $\Delta / \cdot \Lambda$ & $\Lambda \cdot / r$. & احساس تنهايى \\
\hline.$- / 11$ & .1 .99 & $\Delta / / q$ & $11 / T \mathrm{~V}$ & استدلال يدر \\
\hline . & $\cdot / r \Delta q$ & $\Delta / 94$ & 4/ & يرخاشگرى كلامى يدر \\
\hline$\cdot \cdots \wedge$ & $-\cdot$ FrD & $r / \Lambda$. & $r / l$. & يرخاشكرى فيزيكى يدر \\
\hline D MYY & $\cdot / \Delta \wedge \mathrm{V}$ & $q / Y \Delta$ & $|r / q|$ & استدلال مادر \\
\hline.$- / .9$ & $-\cdot / \cdot \wedge r$ & $\Delta / \Delta \Delta$ & $9 / 1 V$ & يرخاشگرى كلامى مادر \\
\hline$-\cdot / 9 Y 9$ & .1919 & $F / .1$ & $1 / 1 r$ & يرخاشخرى فيزيكى مادر \\
\hline$-\cdot / Y 4$ & $-\cdot / \Delta r \Delta$ & $f / F 1$ & V/Vr & دلبستكى نايمن \\
\hline$-\cdot / k a r$ & $-\cdot / r \Delta r$ & $r / r$. & $\mid r / Y r$ & دلبستخى ايمن \\
\hline
\end{tabular}

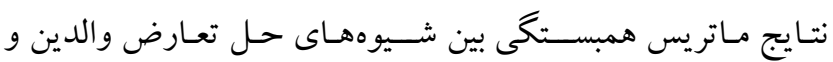

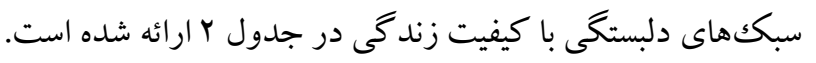

جدول r: ماتريس همبستغى بين شيوههاى حل تعارض والدين و سبككهاى دلبستغى با كيفيت زندكى

\begin{tabular}{|c|c|c|c|c|c|c|c|c|c|}
\hline 9 & $\Lambda$ & $\checkmark$ & 7 & 0 & $\varepsilon$ & $r$ & $r$ & 1 & متغير \\
\hline & & & & & & & & - & 1. كيفيت \\
\hline & & & & & & & - & |r/**** & ז. استدلال يدر \\
\hline & & & & & & - & $-\cdot / \cdot v$ & -.1 .9 & r. كلامى بدر \\
\hline & & & & & - & $\cdot / \Delta \Lambda^{* *}$ & $-.110^{*}$ & $-\cdot / M r$ & F. فيزيكى بدر \\
\hline & & & & - & $\cdot / \cdot 1$ &.$/ \cdot r$ & $\cdot / \mu f^{* * *}$ & $\cdot / Y^{* * *}$ & هـ استدلال مادر \\
\hline & & & - & $.119^{*}$ & $\cdot / \mu r^{* *}$ & $\cdot / \mu^{* *}$ & $-\cdot / l f$ & $-\cdot / M r$ & 9. كلامى مادر \\
\hline & & - & $\cdot / q^{* *}$ & $-\cdot / 11$ & $\cdot / \Delta q^{* *}$ & $\cdot / 4 \wedge^{* *}$ &.$/ \cdot 1$ & $-\cdot / r \cdot * *$ & V. فيزيكى مادر \\
\hline & - & $\cdot / \Lambda^{* *}$ & .1 .9 & .1 .9 & . & .119 & -.1 .4 & $-\cdot|\not|^{* *}$ & م سبك نايمن \\
\hline- & $-\cdot / 19^{* *}$ &.$/ . F$ & $-\cdot / \cdot r$ & $\cdot / r F^{* * *}$ & .1 .0 & rות & $-\cdot / \cdot 1$ & .1 .9 & 9. سبكك ايمن \\
\hline
\end{tabular}

سـاير مؤلفههاى شـيوههاى حل تعارض والدين و سـبك هاى دلبستكى با

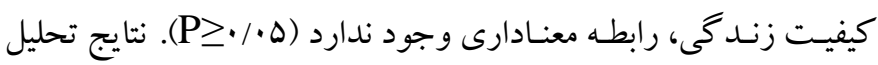
ركرسيون براى بيشبينى كيفيت زندكى دختران بر اساس شيوههاى حل تعارض والدين و سبككهاى دلبستكى در جدول م گزارش شده است.
همانطور كه در جدول Y مشاهده مىشود بين استدلال بدر و استدلال مـادر بـا كيفيـت زنسدكى دختران، همبســــى مثبـت معنـادار؛ و بين برخاشــرى فيزيكى مادر و ســـك دلبســـى نايمن با كيفيت زندكى

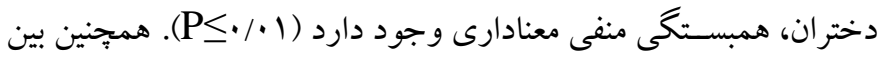


جدول r: نتايج تحليل ركرسيون سهم شيوههاى حل تعارض والدين و سبكهاى دلبستكى در يِيشينى كيفيت زندكى دختران

\begin{tabular}{|c|c|c|c|c|c|}
\hline \multirow{2}{*}{$\mathbf{P}$} & \multirow{2}{*}{$\mathbf{t}$} & \multirow{2}{*}{ ضرايب استاندارد } & \multicolumn{2}{|c|}{ ضرايب غير استاندارد } & \\
\hline & & & S.B & $\mathrm{B}$ & \\
\hline$\cdot / \cdot 1$ & $\mid q / 1$. & & $\Delta / F G$ & $W / \cdot 1$ & مقدار ثابت \\
\hline$\cdot / \cdot 1$ & $r / M$ & . MAY & $\cdot / 19$ & $\cdot / r 4$ & استدلال يدر \\
\hline$\cdot / \mathrm{VA}$ & $\cdot / r \wedge$ & 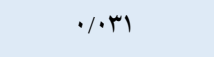 & 年 & .1 .94 & يرخاشكرى كلامى بدر \\
\hline$\cdot / 91$ & $\cdot / \cdot r$ & 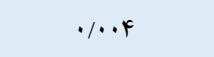 & $\cdot / \mu$ &.$/ 1 r$ & يرخاشگرى فيزيكى بدر \\
\hline$\cdot / \cdot F$ & $r / F V$ & $\cdot / / v$ & $\cdot / 19$ & ./Ir. & استدلال مادر \\
\hline$\cdot / r$ & $-\cdot / r \Delta$ &.$- / \cdot r F$ & $\cdot / r \mid$ & $-\cdot / \cdot V r$ & برخاشخرى كلامى مادر \\
\hline.$/ \cdot 1$ & $-Y / 9 Y$ &.$- / 119$ & $\cdot / \mu F$ & $-\cdot / \mu F \mid$ & يرخاشگُى فيزيكى مادر \\
\hline$\cdot / \cdot 1$ & $-r / A F$ & $-\cdot / T V F$ & $\cdot / r F$ & $-\cdot /$ MIr & دلبستخى نايمن \\
\hline$\cdot / 91$ &.$/ 11$ &.$/ 1$ & $\cdot / \mu F$ & 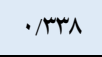 & دلبستخى ايمن \\
\hline
\end{tabular}

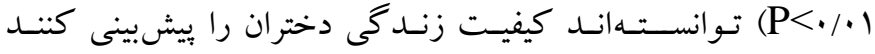
(P<•/1) دختران بر اساس شيوههاى حل تعارض والدين و سبككهاى دلبستخى در جدول F Fز ارش شده است.
بر اساس نتايج جدول ب متغيرهاى شــيوههاى حل تعارض والدين و سبك هاى دلبستگى، اس درصد توانايى بيشبينى كيفيت زندكى دختران

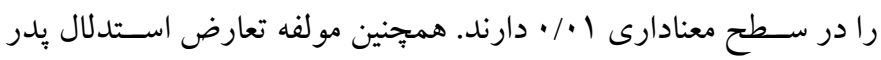

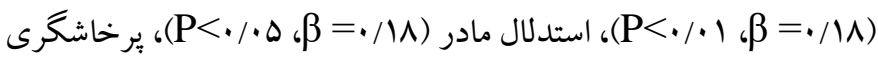

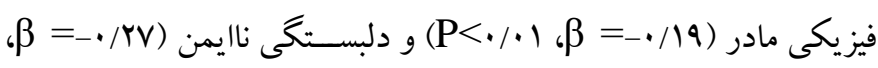

جدول ع: نتايج تحليل ركرسيون سهم شيوههاى حل تعارض والدين و سبككهاى دلبستكى در ييشبينى احساس تنهايى دختران

\begin{tabular}{|c|c|c|c|c|c|}
\hline \multirow{2}{*}{ سطح معنىدارى } & \multirow{2}{*}{ Tاره } & \multirow{2}{*}{ ضر ايب استاندارد } & \multicolumn{2}{|c|}{ ضر ايب غير استاندارد } & \multirow{2}{*}{ متغير } \\
\hline & & & S.B & $\mathrm{B}$ & \\
\hline.$/ \cdot 1$ & HN/IT & & r/rr & $M / 90$ & مقدار ثابت \\
\hline.$/ \cdot 1$ & $-Y / 9 \Lambda$ & $-\cdot / r \mid$ &.$/ \cdot 9$ & $-\cdot / 1 \mathrm{VV}$ & استدلال يدر \\
\hline$\cdot / 49$ & $\cdot / N F$ & $\cdot / \cdot \wedge r$ &.$/ 11$ & .1 .44 & يرخاشخرى كلامى يدر \\
\hline$\cdot / \Delta \Lambda$ & $\cdot / \Delta 9$ & $\cdot / \cdot V F$ & ./Mr &.$- / .9 r$ & يرخاشگرى فيزيكى بدر \\
\hline$\cdot / N^{F}$ & $-\cdot / / q$ & $-\cdot / \cdot \Delta \wedge$ & 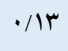 & $-\cdot / \cdot r 1$ & استدلال مادر \\
\hline.$/ \cdot r$ & Y/AY & $\cdot /$ ITF &.$/ \cdot 9$ &.$/ 1 F \Delta$ & يرخاشخرى كلامى مادر \\
\hline$\cdot / 09$ & $\cdot / k T$ & $\cdot / \cdot v r$ & $\cdot / \cdot \wedge$ &.$/ .94$ & يرخاشگرى فيزيكى مادر \\
\hline.$/ 1$ & $r / V I$ & $\cdot / \mathrm{AV}$ &.$/ 11$ & $\cdot / r \cdot 1$ & دلبستكى نايمن \\
\hline.$/ \cdot 1$ & $-Y / A V$ &.$- / 199$ & $\cdot / 10$ & $-\cdot / r V I$ & دلبستخى ايمن \\
\hline
\end{tabular}

توانســنــد كيفيـت زنـدكى دختران را بـه طور معنـادارى بيش بينى كنند

$$
(\mathrm{P}<\cdot / 1)
$$

بر اسـاس نتايج جدول f متغيرهاى شـيوههاى حل تعارض و الدين و سبك هاى دلبستكى 19 درصد، توانايى يبيشبينى احساس تنهايى دختران را در سطح معنادارى ه • • دارند. همجنين مؤلفه برخاشخرى كلامى مادر ( $)$

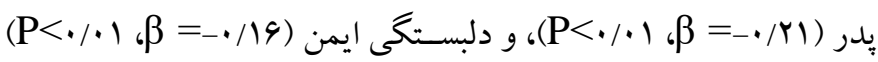


فرزندان مىشــود كه با نتايج يزوهش حاضـــر در تعارض اســت (YI).

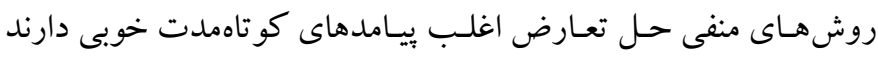

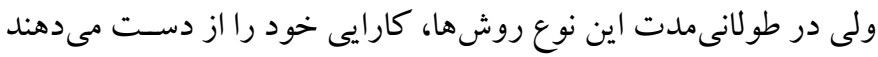
و موجب مىشـوند تا صميميت، اعتماد و صداقت جاى خود را به خشم،

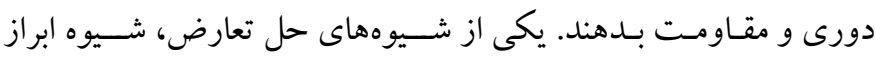

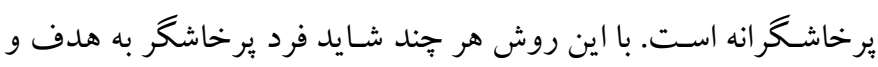

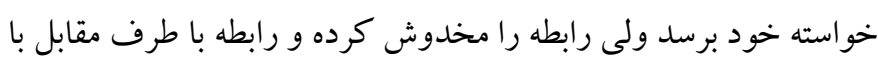

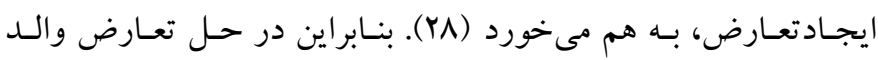

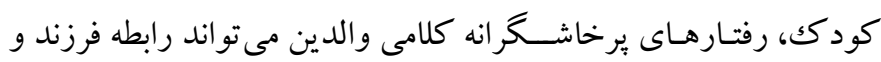

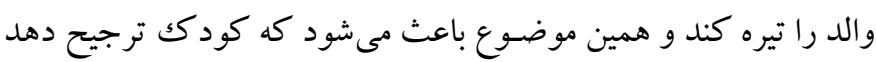

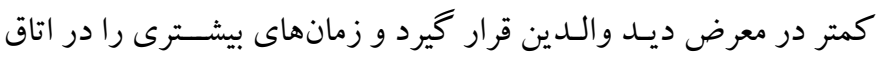

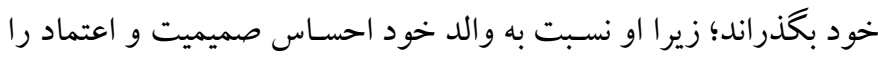

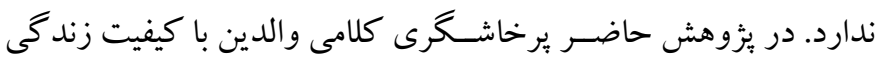

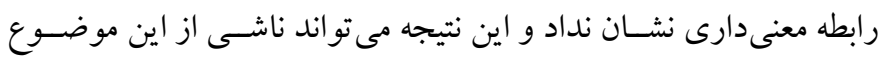

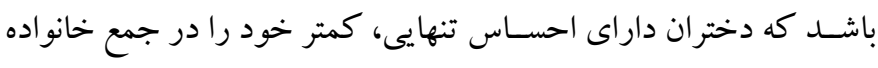

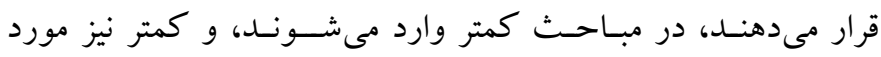

$$
\text { يرخاشخرى كلامى قرار مى گيرند (1N). }
$$

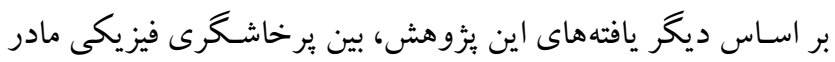

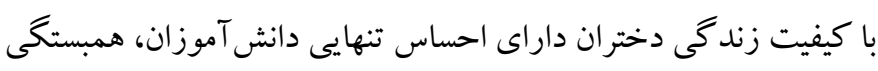

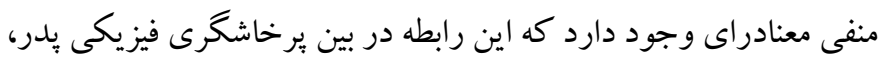

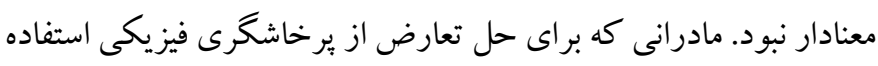

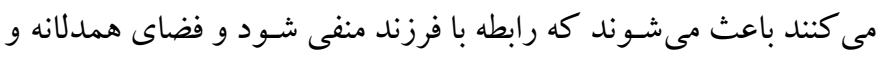

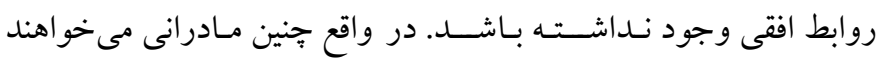

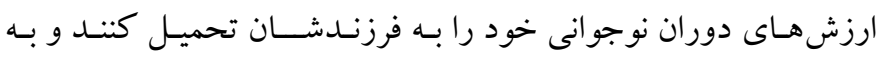
ارزشهاى فرزند خود توجه نمى كنند. اين موضسوع موجب خشـم در هر

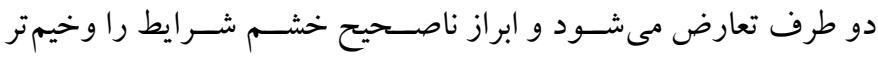

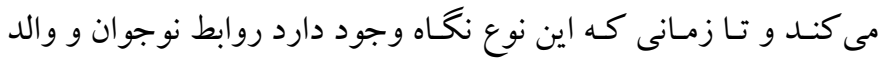

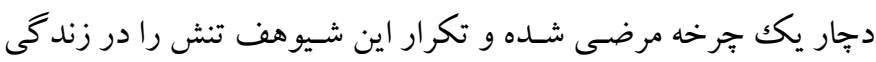

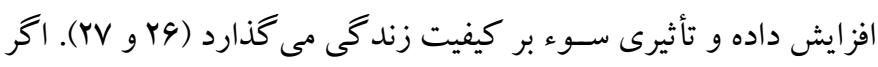

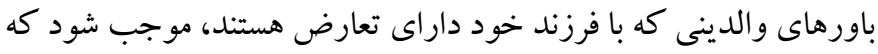

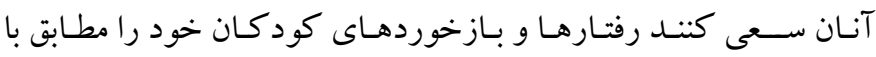

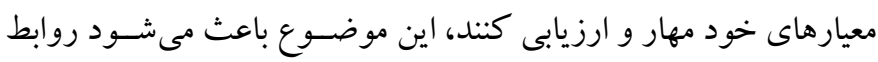

\section{بحث و نتيجه كيرى}

مطالعه حاضــر با هدف بروسته كيرى رابطه شــيوههاى حل تعارض والدين و

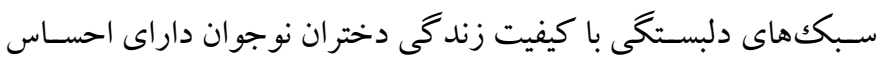

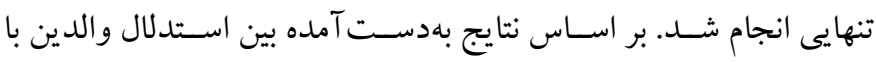

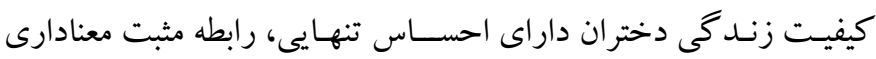

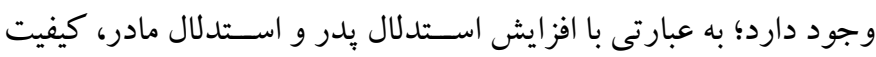

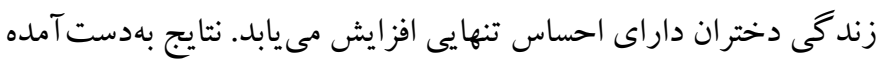

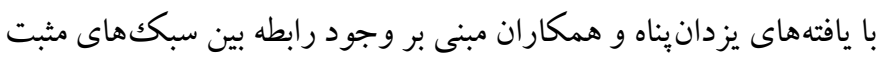

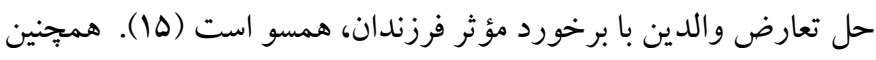

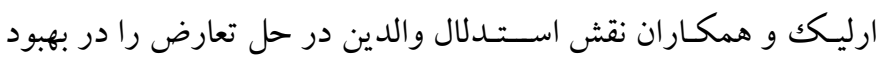

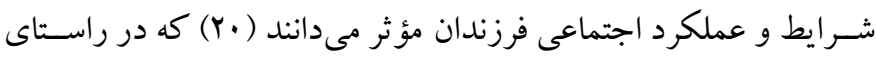
نتايج اين مطالعه است. افرادى كه داراى احسـاس تنهايى هسـتند به دليل اين كه از ارتباط

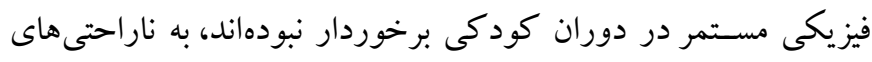
جسـمانى و عاطفى دجار مىشـوند، از حرمت خود بِايينى برخوردار

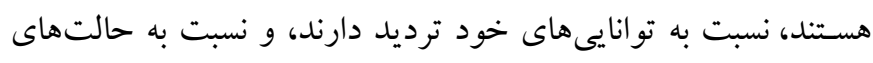

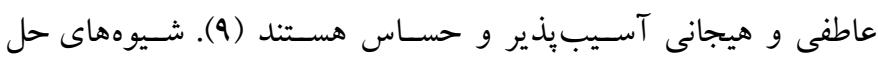

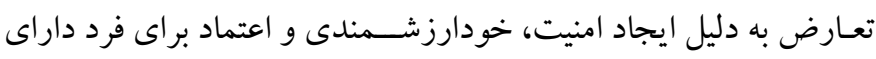

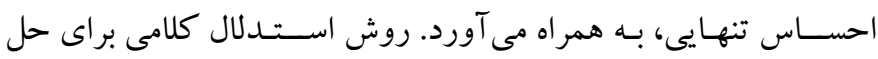

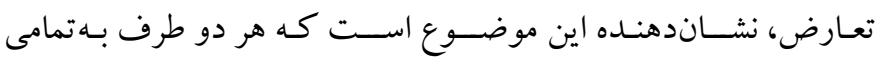

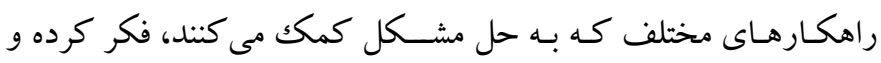

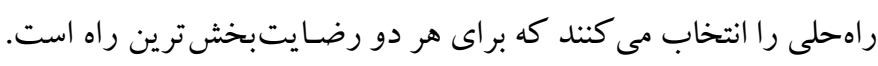

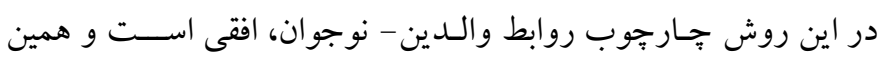

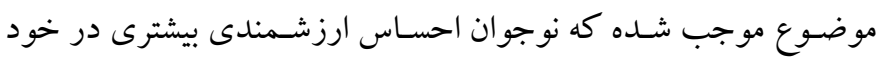

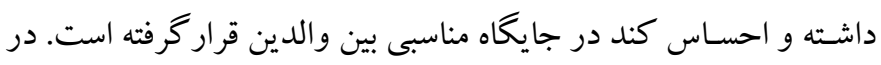
نتيجه همين احساسات مثبت به فرد كمكك مى كند كه شرايط بهترى را از

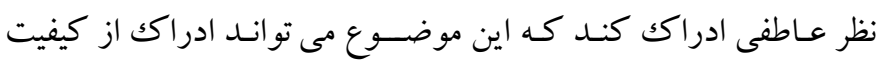

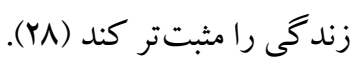

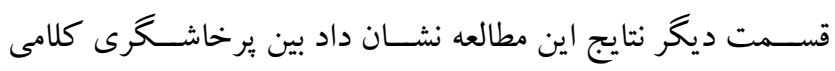

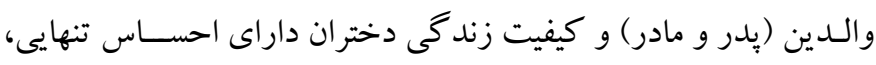
رابطه معنى دارى وجود ندارد. در بزٔوهش هاى كنتز لر و همكاران نشــان

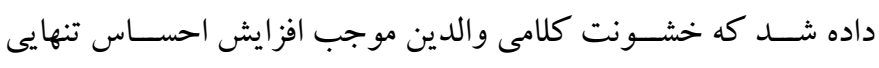


كافيتوس و سايدرايدز نيز نشان دادند كه دلبستحى نايمن، رفاه و كيفيت

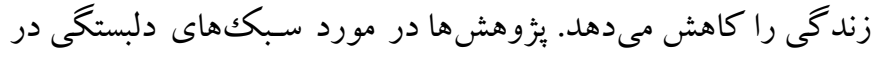

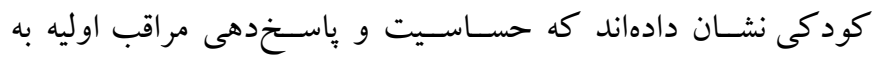
حالتهاى هيجانى كودك، تعيين كننده اصسلى يادگيرى روش تنظيم

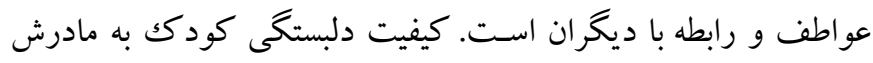

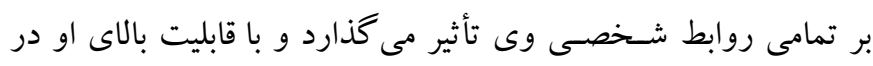

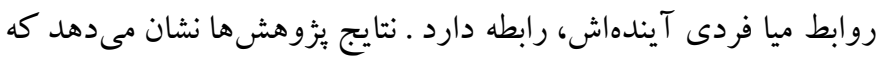

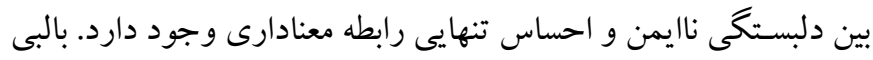

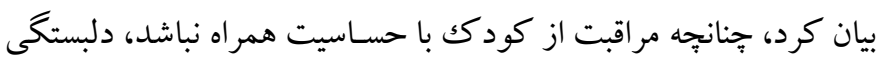
نايمن در كودك شـكل مى گيرد و الكوهاى عملى درونى او از ديخران

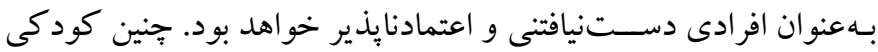
خود را شـايسته دريافت مراقبت تو أم با حسـاسيت در نظر نمى گيرد. اين

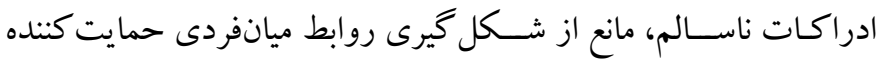

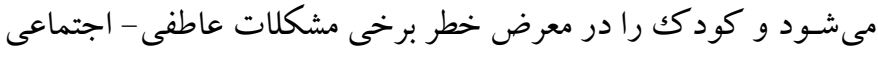
قرار مىدهد كه در كود كان احساس تنهايى، تجربه مىشود. اين احساس تنهايى در دوران نوجوانى نيز ادامه مى يابد و برخى اوقات حتى بيشتر هم

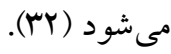
نتيجه ديخر اين بزّوهش نشـان داد متغيرهاى شـــوهـاى حل تعارض

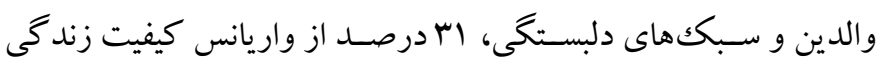

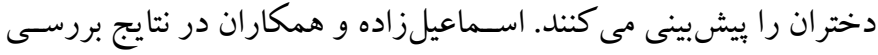
خود نشـان دادند ســبك هاى مديريت تعارض توانايى بيشبينى كيفيت زندگى را دارند (1) ). شـيوههاى مختلفى براى حل تعارض وجود دارد

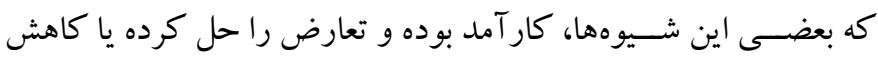

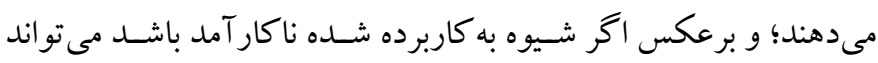

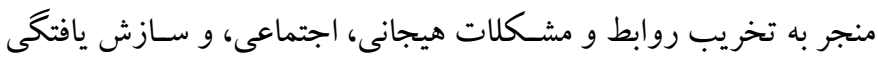

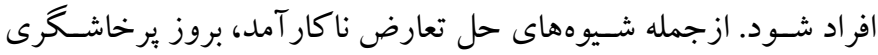
بهمنظور حل تعارض است (9). يرخاش در تعارضات شامل رفتارهايى

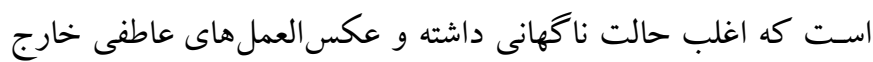

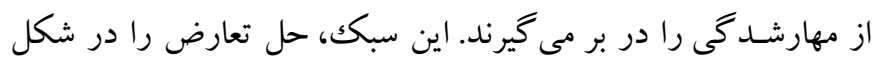

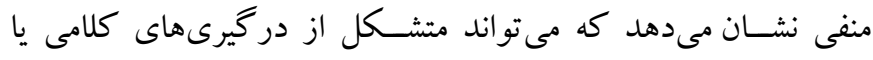
فيزيكى باشـد كه با هدف تحميل انطباق يا كناره گيرى انجام مى شــود

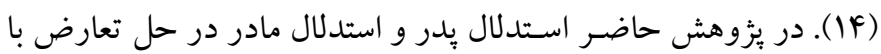

آنها مخدوش شـود. اين نوع مهارگرى و ترس ناشسى از آن، به فرزندان اجازه نمىدهد كه احسـاسـات خود را آزادانه بروز دهند و از طرفى نيز عو اطف و احسـاسـاتى هم كه از والدين دريافت مى شــود، مهار شــده و

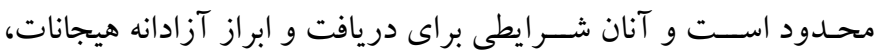
احسـاسات، و عواطف ندارند و جنين مسئلهاى مانع ايجاد روابط مثبت و سازشيافته بين والد و فرزند مى شود (FF).

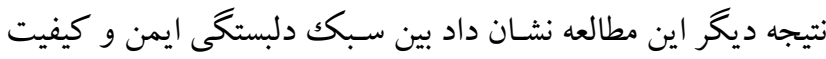

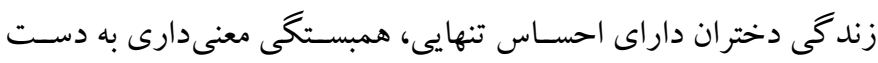

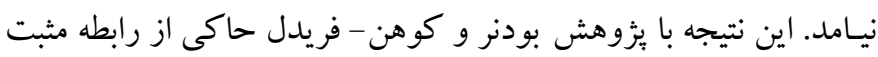

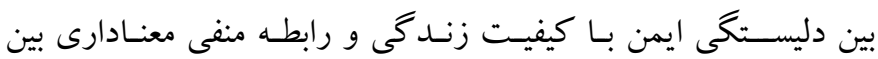

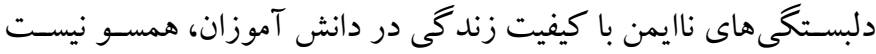
(Y9). بالبى در تأكيد بر اهميت ارتباط مادر و كودك معتى معتقد اسـت كه براى سـلامت روانى و تحول هيجانى و عاطفى مطلوب كودكى، تجربه

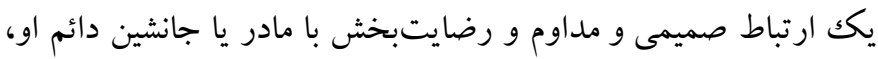

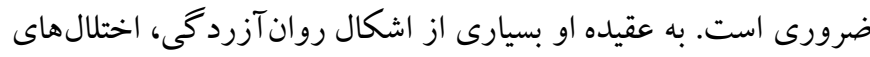
شخصيتى، ناتوانىهاى ارتباطى، و هيجانى حاصل محروميت كودكى از

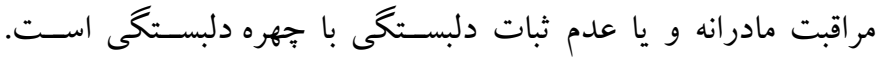

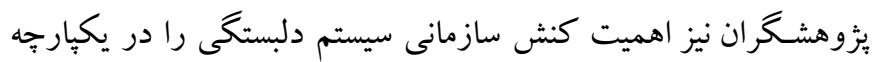
كردن مؤلفههاى عاطفى، انظخيزشىى، شـناختى، و رفتارى مورد تأكيد

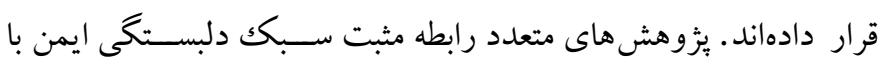

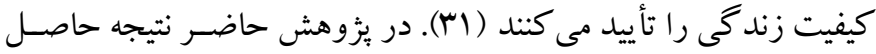
رابطه معنى دارى را بين سبك دلبستخى ايمن و كيفيت زندگى نشان نداد

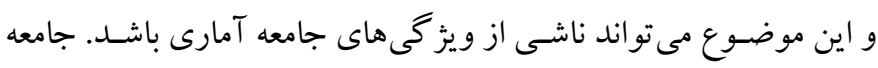
مورد مطالعه در اين يزوهش، دختران داراى احساس تنهايى بودند كه اين

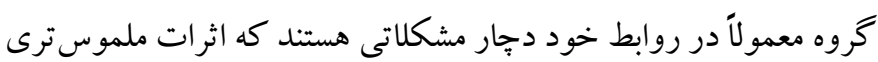
در كيفيت زندكى اين افراد نشـان مى دهد و نقش سبكك دلبستخى ايمن اين افراد را تعديل مى كند.

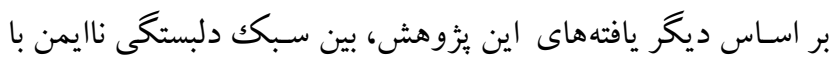

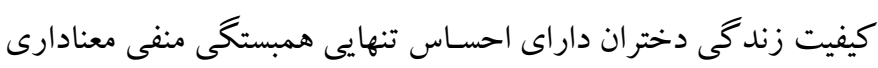

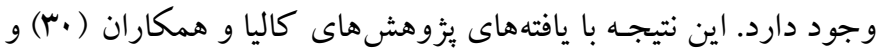

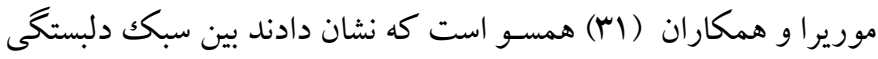
نايمن اجتنابى با كيفيت زندگى رابطه منفى معنى دار وجود دارد. همجينين 


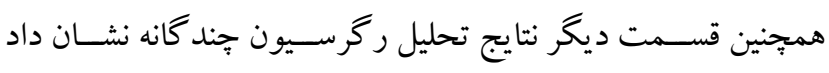

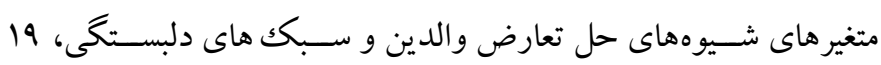

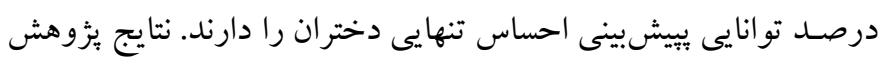

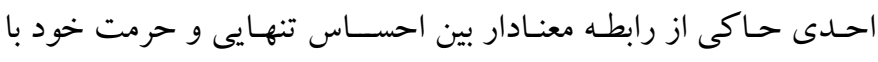

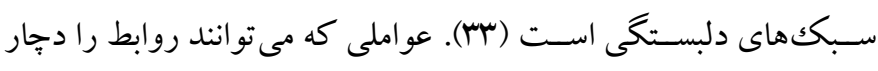

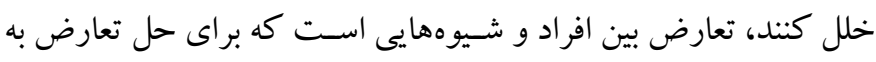

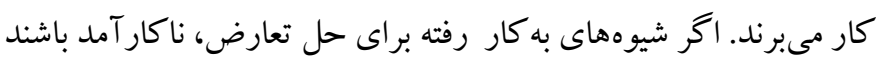

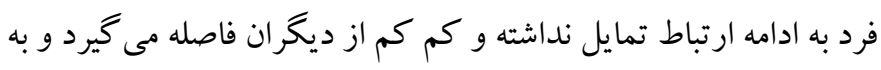

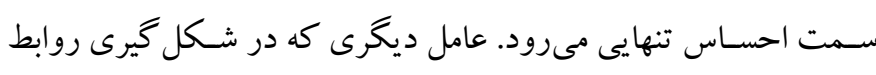

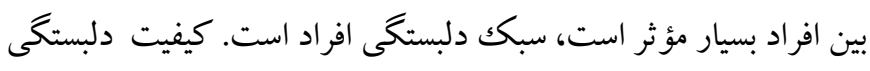

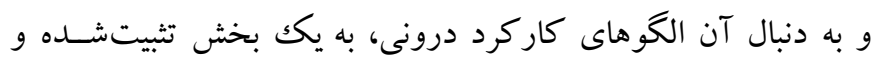

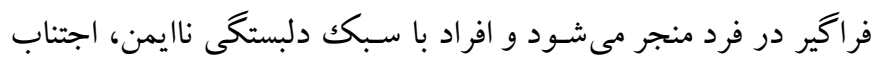

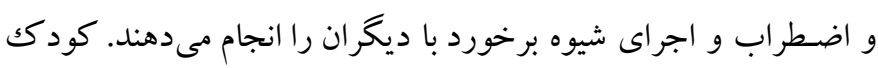

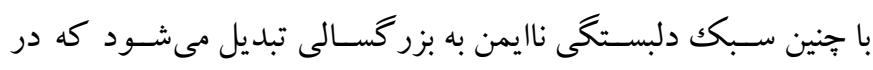

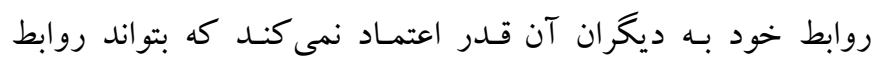

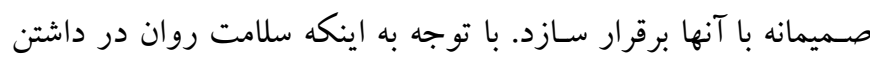

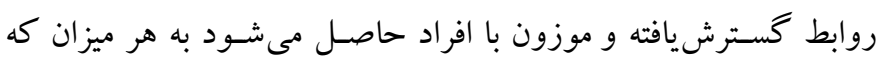
فردى روابط صـميمانه و سـالمى با ديخران داشـته باشد به همان اندازه

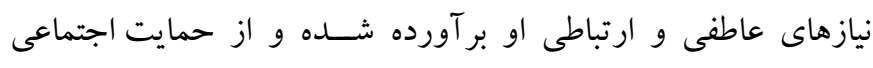

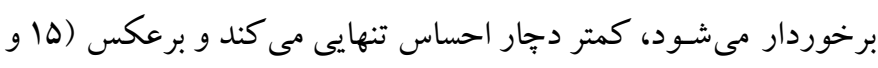

در نهايت مى توان بيان كرد كه شـيوه حل تعارض والدين و سـبكك

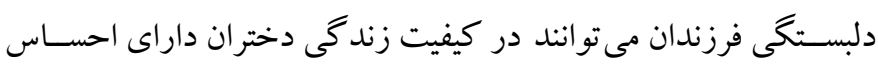

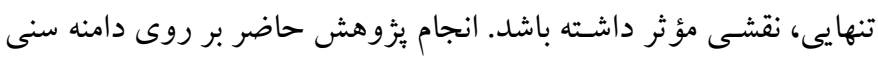

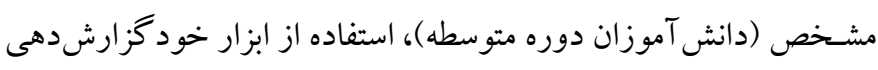

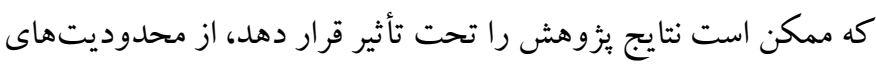

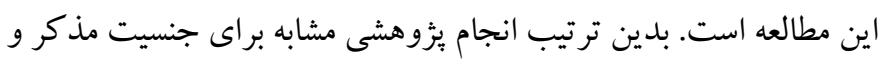

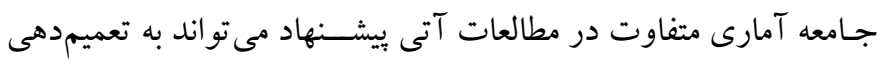

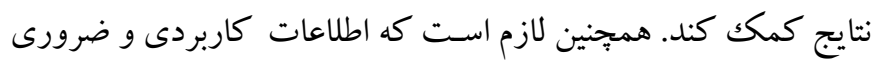

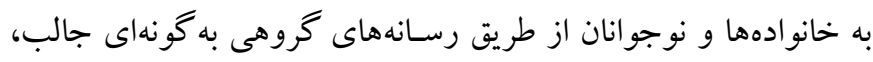

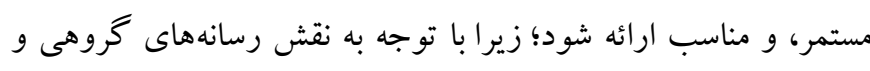

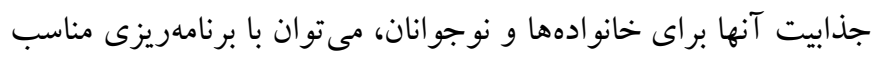

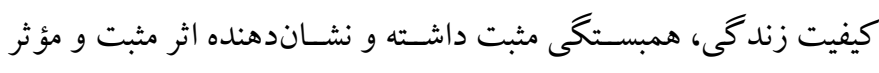

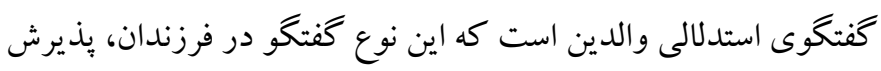

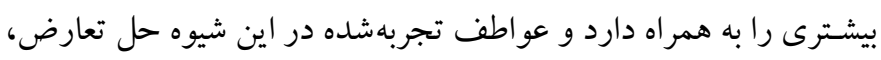

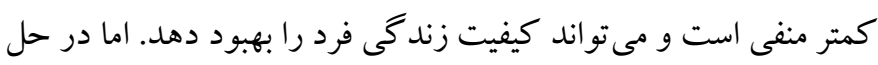

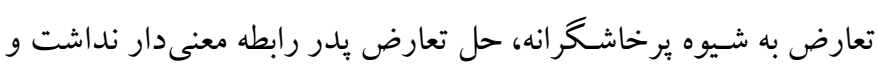

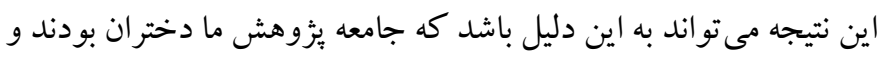

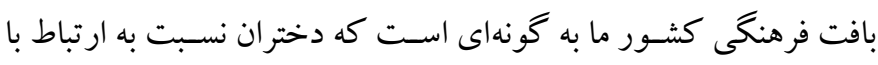

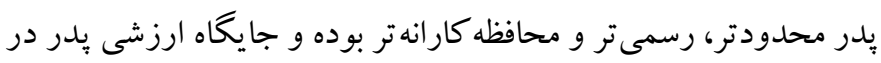

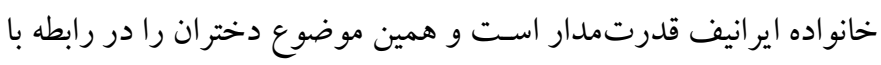

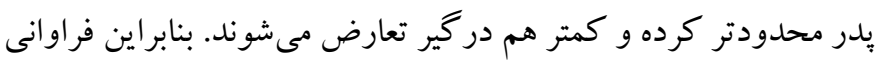

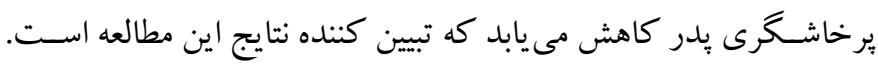

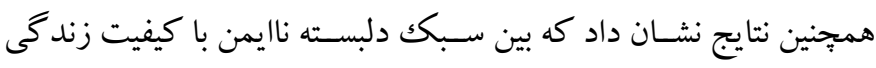

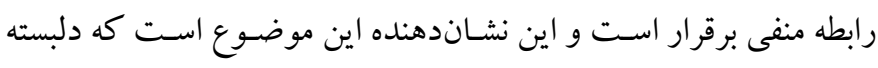

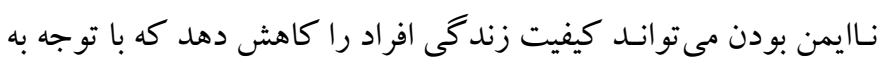

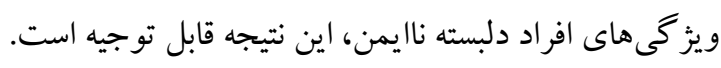

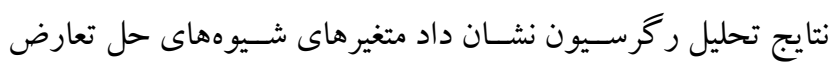

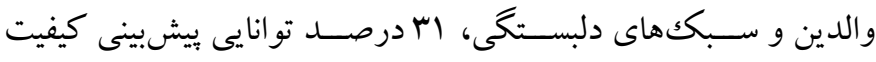

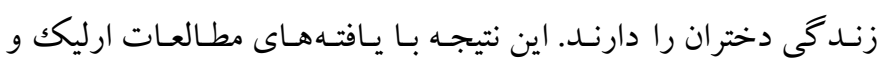

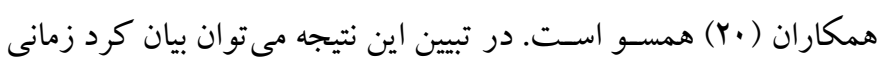

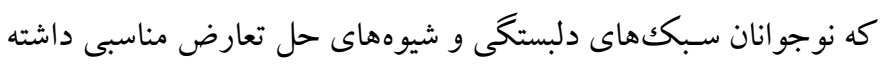

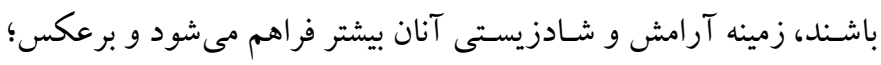

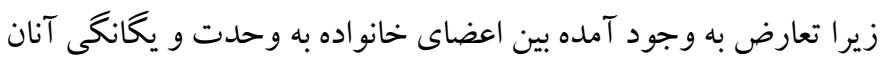

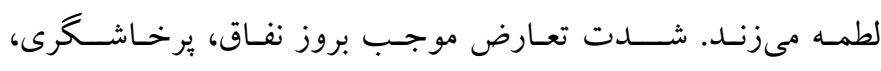

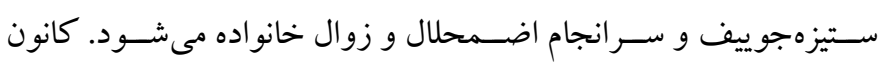
خانو ادهاى كه بر اثر تعارض و جدال بين اعضاى آن، آشفته است، محيط

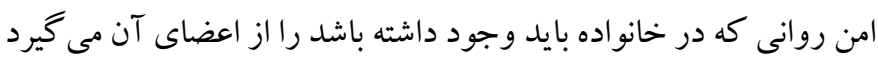

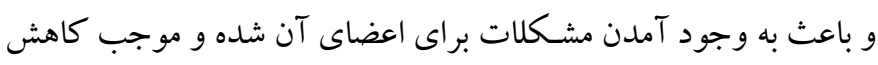

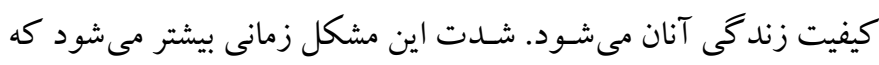

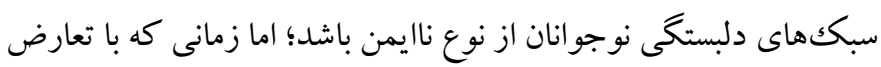

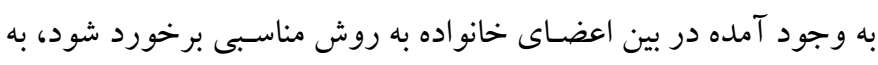

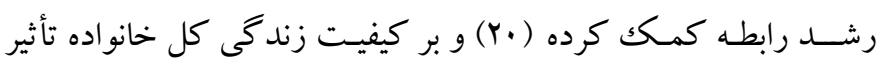
مى كذارد. 
تشكر و قدردانى: اين يزوهش بهطور مستقل انجام شده است و مجوز اجراى

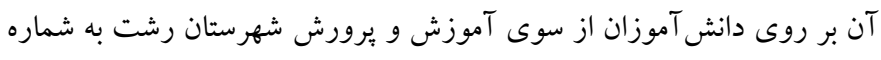

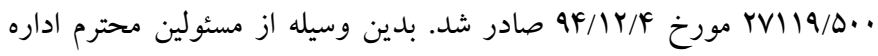
آموزشويرورش، دانش آموزان شر كت كننده در اين مطالعه، و همجنين مسئولين مدارس، تشكر و قدردانى به عمل مى آيد.

تضاد منافع: بدينوسيله اعلام مىشود كه اين مطالعه هيج گونه تضاد منافعى را

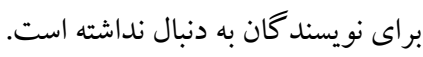

در اين زمينه، بخشسى از آموزش خانوادهها و نوجوانان را انجام داد. همجنين در مدارس جلسـات آموزشى منظم و مناسب براى خانو ادهها

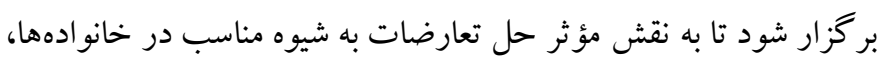

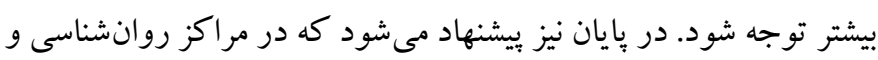
مشاوره، در درمان افراد داراى احساس تنهايى، سبكك دلبستخى آنها مورد توجه فزاينده قرار گيرد. 


\section{References}

1. Khormaei F, Zarei Manoujan N. The relation between girls and boys from the perspective of adolescent girls: a qualitative study. Biannual Journal of Applied Counseling. 2016; 6(2): 89-106. [Persian]. [Link]

2. Nkyi A. Lonless among senior high school student in Ghana. British Journal of Psychology Research. 2014; 2(1): 1-13. [Link]

3. Qualter P, Rotenberg K, Barrett L, Henzi P, Barlow A, Stylianou $\mathrm{M}$, et al. Investigating hypervigilance for social threat of lonely children. J Abnorm Child Psychol. 2013; 41(2): 325-338. [Link]

4. Hawkley LC, Cacioppo JT. Loneliness matters: a theoretical and empirical review of consequences and mechanisms. Ann Behav Med. 2010; 40(2): 218-227. [Link]

5. Vanhalst J, Klimstra TA, Luyckx K, Scholte RHJ, Engels RCME, Goossens L. The interplay of loneliness and depressive symptoms across adolescence: exploring the role of personality traits. $\mathbf{J}$ Youth Adolesc. 2012; 41(6): 776-787. [Link]

6. Henrich LM, Gullone E. The clinical significance of loneliness: a literature view. Clin Psychol Rev. 2006; 26(6): 695-718. [Link]

7. Post MWM. Definitions of quality of life: what has happened and how to move on. Top Spinal Cord Inj Rehabil. 2014; 20(3): 167-180. [Link]

8. Gonyea JG, Curley A, Melekis K, Levine N, Lee Y. Loneliness and depression among older adults in urban subsidized housing. J Aging Health. 2018; 30(3): 458-474. [Link]

9. Khalatbari J, Ghorbanshiroudi S, Hosseini I. An investigation of the relationship between perfectionism and feeling of loneliness and the life quality of medical students in guilan province. Journal of Educational Psychology. 2011; 2(1): 117-131. [Persian]. [Link]

10. Haggerty KP, McGlynn-Wright A, Klima T. Promising parenting programs for reducing adolescent problem behaviors. J Child Serv. 2013; 8(4): 10-16. [Link]

11. Smith SB, Tutor RS, Phillips ML. Resolving conflict realistically in today's health care environment. J Psychosoc Nurs Ment Health Serv. 2001; 39(11): 3645. [Link]

12. Ali NS, Khalil HZ. Effect of psychoeducational intervention on anxiety among Egyptian bladder cancer patients. Cancer Nurs. 1989; 12(4): 236-242. [Link]
13. Kalmijn M. Contact and conflict between adult children and their parents in immigrant families: is integration problematic for family relationships? J Ethn Migr Stud. 2019; 45(9): 1419-1438. [Link]

14. Lue T, Wishon PM, McDevitt TM, Walsh WM. The relationship between marital discord and young children's social problem-solving strategies: the roles of modeling and parenting. Early Child Dev Care. 2011; 137(1): 1-19. [Link]

15. Yazdanpana MH, Hazrati A, Kiani S, Ashrafabadi M. The role of parent's conflict resolution styles in children's social adjustment and their social problem solving. Social Welfare Quarterly. 2013; 12(47): 267279. [Persian]. [Link]

16. Esmaeilzadeh M, Iravani MR, Ghojavand K. Study relationship between conflict management styles and marital life quality among spouses, parents of elementary school students of 3 districts in Esfahan city. Advanced Social Humanities and Management. 2015; 2(1): 88-93. [Link]

17. Kumar SA, Mattanah JF. Interparental conflict, parental intrusiveness, and interpersonal functioning in emerging adulthood. Pers Relatsh. 2018; 25(1): 120-133. [Link]

18. Overton AR, Lowry AC. Conflict management: difficult conversations with difficult people. Clin Colon Rectal Surg. 2013; 26(4): 259-264. [Link]

19. Koçak A, Mouratidis A, Sayıl M, Kındap-Tepe Y, Uçanok Z. Interparental conflict and adolescents' relational aggression and loneliness: the mediating role of maternal psychological control. J Child Fam Stud. 2017; 26(12): 3546-3558. [Link]

20. Ehrlich KB, Dykas MJ, Cassidy J. Tipping points in adolescent adjustment: Predicting social functioning from adolescents' conflict with parents and friends. J Fam Psychol. 2012; 26(5): 776-783. [Link]

21. Gentzler AL, Oberhauser AM, Westerman D, Nadorff DK. College students' use of electronic communication with parents: links to loneliness, attachment, and relationship quality. Cyberpsychol Behav Soc Netw. 2011; 14(1-2): 71-74. [Link]

22. Bazzazian S, Besharat MA. Attachment styles, illness perception and quality of life in patients with type I diabetes. Contemporary Psychology. 2010; 5(1): 3-11. [Persian]. [Link]

23. Safaie $S$. The relationship between attachment style and social development in dyslexic and normal children. Exceptional Education Journal. 2014; 1(123): 29-35. [Persian]. [Link]

24. Fraley RC, Hudson NW, Heffernan ME, Segal N. Are adult attachment styles categorical or dimensional? A 
taxometric analysis of general and relationshipspecific attachment orientations. J Pers Soc Psychol. 2015; 109(2): 354-368. [Link]

25. Ainsworth MDS, Blehar MC, Waters E, Wall SN. Patterns of attachment: a psychological study of the strange situation. 1st Edition. New York: Psychology Press; 2015. [Link]

26. Yárnoz-Yaben S. Attachment style and adjustment to divorce. Span J Psychol. 2010; 13(1): 210-219. [Link]

27. Błachnio A, Przepiorka A, Boruch W, Bałakier E. Self-presentation styles, privacy, and loneliness as predictors of Facebook use in young people. Pers Individ Dif. 2016; 94: 26-31. [Link]

28. Varghese ME, Pistole MC. College student cyberbullying: self-esteem, depression, loneliness, and attachment. Journal of College Counseling. 2017; 20(1): 7-21. [Link]

29. Bodner E, Cohen-Fridel S. Relations between attachment styles, ageism and quality of life in late life. Int Psychogeriatr. 2010; 22(8): 1353-1361. [Link]

30. Calia R, Lai C, Aceto P, Luciani M, Camardese G, Lai $\mathrm{S}$, et al. Attachment style predict compliance, quality of life and renal function in adult patients after kidney transplant: preliminary results. Ren Fail. 2015; 37(4): 678-680. [Link]

31. Moreira H, Gouveia MJ, Carona C, Silva N, Canavarro MC. Maternal attachment and children's quality of life: the mediating role of self-compassion and parenting stress. J Child Fam Stud. 2015; 24(8): 2332-2344. [Link]
32. Kafetsios K, Sideridis GD. Attachment, social support and well-being in young and older adults. J Health Psychol. 2006; 11(6): 863-875. [Link]

33. Ahadi B. Relationship between loneliness and selfesteem with students' attachment styles. Journal of Psychological Studies. 2009; 5(1): 95-112. [Persian]. [Link]

34. Asher SR, Hymel S, Renshaw PD. Loneliness in children. Child Dev. 1984; 55(4): 1456-1464. [Link]

35. Rezaei AM, Safaei M, Hashemi FS. Psychometric properties of the student loneliness feeling scale (SLFS). Journal of Clinical Psychology. 2013; 5(3): 81-90. [Persian]. [Link]

36. Nejat S, Montazeri A, Holakouie Naieni K, Mohammad K, Majdzadeh S. The world health organization quality of life (WHOQOL-BREF) questionnaire: translation and validation study of the Iranian version. Journal of School of Public Health and Institute of Public Health Research. 2006; 4(4): 112. [Persian]. [Link]

37. Riahi M, Esmaeili M, Kazemian S. The effects of mindfulness training to mothers on improving parentchild relationship. Clinical Psychology Studies. 2018; 8(29): 113-135. [Persian]. [Link]

38. Hazan C, Shaver P. Romantic love conceptualized as an attachment process. J Pers Soc Psychol. 1987; 52(3): 511-524. [Link]

39. Rahimian Boogar E, Asgharnejad Farid AA. The relationship between psychological hardiness also ego-resiliency and mental health in adolescent and adult survivors of bam earthquake. Iranian journal of psychiatry and clinical psychology. 2008; 14(1): 6270. [Persian]. [Link] 